$1-1-1942$

\title{
Farming adjustments and agricultural conservation programs in West Virginia
}

\author{
F. D. Cornell \\ C. W. Crickman
}

Follow this and additional works at: https://researchrepository.wvu.edu/ wv_agricultural_and_forestry_experiment_station_bulletins

\section{Digital Commons Citation}

Cornell, F. D. and Crickman, C. W., "Farming adjustments and agricultural conservation programs in West Virginia" (1942). West Virginia Agricultural and Forestry Experiment Station Bulletins. 304.

https://researchrepository.wvu.edu/wv_agricultural_and_forestry_experiment_station_bulletins/305 @ WVU. It has been accepted for inclusion in West Virginia Agricultural and Forestry Experiment Station Bulletins by an authorized administrator of The Research Repository @ WVU. For more information, please contact ian.harmon@mail.wvu.edu. 
West Virginia University Libraries

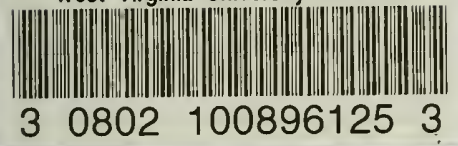





\section{FOREWORD}

The discussion herein relative to the Agricultural Conservation Programs does not purport to be a complete evaluation of such programs. This presentation deals particularly with a study of only a few aspects of the regional program as compared with the special provisions of the Upshur County program. The value of the programs as a whole and the benefits under them have been amply demonstrated and are too well known to need review. However, efforts are constantly being made to improve the programs so that they may be adapted even better to the areas to which they apply. The special program herein described was a phase of such study. 


\section{CONTENTS}

Page

Introduction and Description of Area ............................................... 5

Type of Farming and Farm Organization ....................................... 7

Specialized Types ................................................................... 9

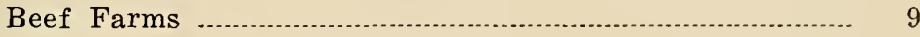

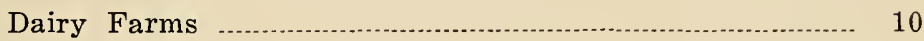

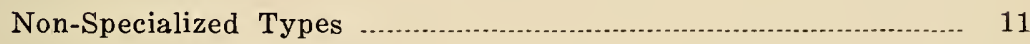

Self-Sufficing Farms ..................................................... 11

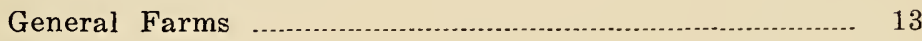

Part-Time Farms ...................................................... 13

Livestock Enterprises Outstanding ......................................... 15

Farm-Adjustment Problems in the Area .......................................... 16

The Pasture Problem ................................................................. 16

The Balance Between Crop and Pasture Land ................. 19

The Low-Income Farm Problem ............................................. 20

Agricultural Conservation Programs ................................................... 21

The State Programs ................................................................ 22

The Upshur County Experimental Program ............................. 23

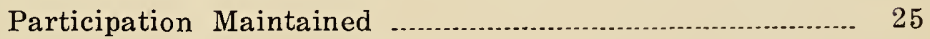

Materials in Lieu of Payment .................................... 28

Pasture Improvement .............................................. 29

Pasture Improvement Under the State vs. the Experimental Program

Seedings

Results Obtained Under the Experimental Program......... 36

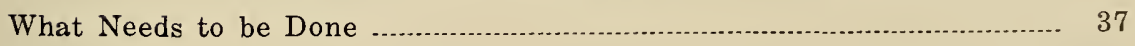

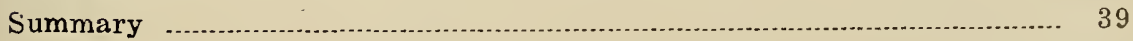


Digitized by the Internet Archive in 2010 with funding from

Lyrasis Members and Sloan Foundation 


\title{
FARMING ADJUSTMENTS AND AGRICULTURAL CONSERVATION PROGRAMS IN WEST VIRGINIA
}

\author{
By F. D. Comell, Jr.,* and C. W. Crickman
}

\section{INTRODUCTION AND DESCRIPTION OF AREA}

7 HE STUDY herein reported deals with farm-management 1 problems, particularly with the adaptability of the provisions of the state and the Upshur County agricultural conservation programs to farms in the north-central pasture area of West Virginia. The area studied included Upshur, Harrison, Lewis, and Braxton Counties (Fig. 1). These counties are typical of the larger livestock-grazing area found in the north and west-central part of the state. They are characterized by hilly topography and by a large proportion of the total farm land in pasture. Many small, self-sufficing farms are found in the area. However, the beef-cattle enterprise predominates throughout.

The typically hilly topography of the state, and of the north-central pasture area in particular, is responsible for many problems of land use and farm management. Slope is an outstanding factor in determining the suitability of land for certain agricultural uses. As the slope increases, erosion becomes more severe, fertility is more difficult to maintain, and costs of production increase. Land having a slope of 25 percent or more should generally be used for pasture or forest. Approximately 70 percent of the land in the counties studied falls in this category (Table 1). Sixty-three percent of all land in farms in these four counties was in pasture in 1935. Most of the land suitable for crops is included in the first two slope classes shown in Table 1 . The areas of comparatively level land are limited and are found principally along the streams and on the tops of the plateaus.

\section{Acknowledgment}

In this project the Agricultural Experiment Station of West Virginia University has cooperated with the Bureau of Agricultural Economics and the Agricultural Adjustment Administration of the United States Department of Agriculture.

The assistance of members of the technical staffs of the cooperating agencies, of the Upshur County A. C. P. committee and agricultural leaders, of county workers in Harrison, Braxton, and Lewis Counties, of the state A. A. A. office, and of the farmers in the area studied is gratefully acknowledged.

* Associate Agricultural Economist, West Virginia Agricultural Experiment Station. tSenior Agricultural Economist, Bureau of Agricultural Economics, Washington, D. C. 


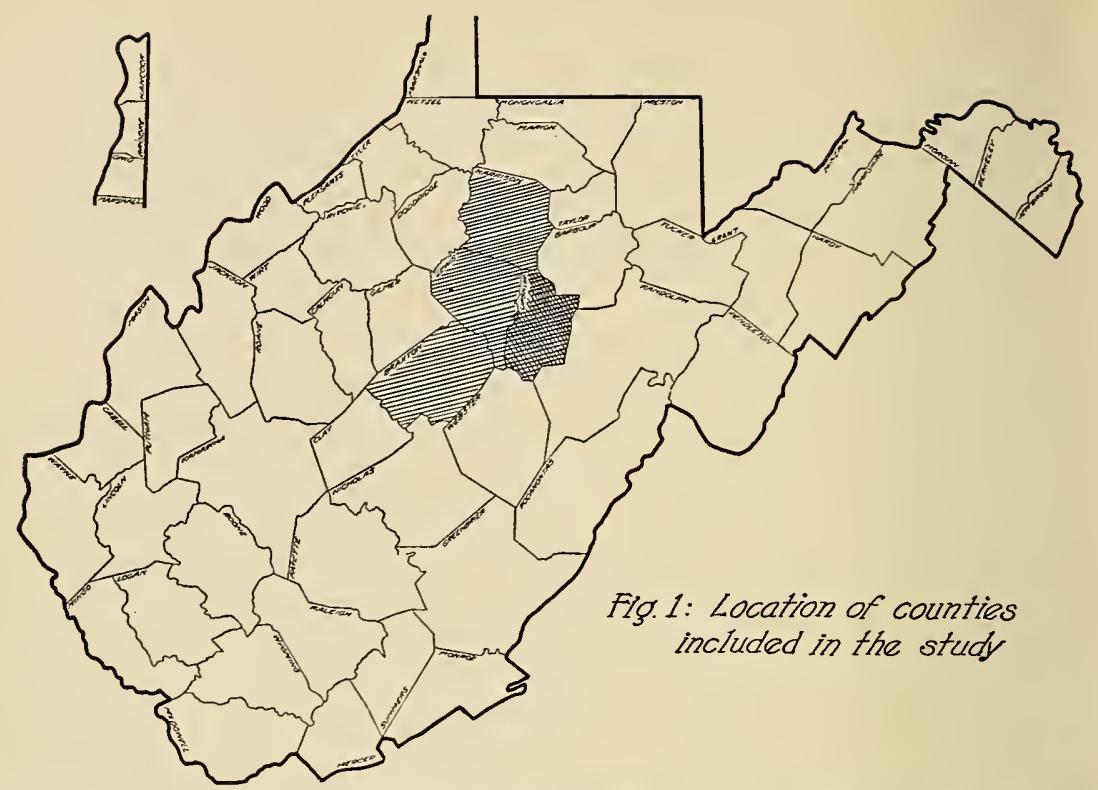

Table 1-Percentage of Land Area in Different Slope Classes in Upshur, Harrison, Braxton, and Lewis Counties

\begin{tabular}{|c|c|c|}
\hline \multicolumn{2}{|c|}{$\begin{array}{l}\text { Slope } \\
\text { class }\end{array}$} & $\begin{array}{l}\text { Percentage of total } \\
\text { land area }\end{array}$ \\
\hline $\begin{array}{r}0-12 \\
12-25 \\
25-40 \\
\text { More than } 40\end{array}$ & $\begin{array}{l}\text { percent } \\
\text { percent } \\
\text { percent } \\
\text { percent }\end{array}$ & $\begin{array}{l}13.1 \\
16.7 \\
50.8 \\
19.4\end{array}$ \\
\hline
\end{tabular}

On the basis of soil surveys of all but two counties in the state, only 5.5 percent of the soils are bottom-land soils, and 2.3 percent terrace soils. Approximately 69 percent of the soils can be classified as non-limestone upland soils. Only about 11 percent are upland soils with some limestone influence. Most of the soils of the north-central area are upland soils deficient in lime. They fall chiefly into the Dekalb, Meigs, Upshur, and Westmoreland series.

The soils of West Virginia have been classified as to use on the basis of combined fertility, slope, and erosion index. The important classes from an agricultural viewpoint are:

Land Class I-Superior cropland

Land Class II-Good cropland

Land Class III-Average cropland

Land Class IV-Below average cropland or good pasture

Land Class V-Inferior cropland or average pasture 
Table 2 shows the percentages of the land in the four counties that fall in the foregoing land classes. Approximately 60 percent of the land in these counties has agricultural possibilities. The rest is either sub-marginal for agriculture or is in urban and industrial use.

Table 2-Percentage of the Total Land Area in Harrison, Braxton, Lewis, and Upshur Counties in the Various Land Classes

\begin{tabular}{|c|c|}
\hline Land class & $\begin{array}{l}\text { Percentage of total } \\
\text { land area }\end{array}$ \\
\hline $\begin{array}{l}\text { II } \\
\text { III } \\
\text { IV } \\
\text { V }\end{array}$ & $\begin{array}{r}0.0 \\
2.9 \\
1.8 \\
16.9 \\
40.9\end{array}$ \\
\hline
\end{tabular}

Most of the land in these four counties has been subject to moderate sheet erosion, with the result that the depth of the surface layer has been reduced by from 25 to 75 percent. Considerable acreages of pasture land as well as cropland have been seriously depleted in recent years. Farmers are just beginning to realize that they are dependent upon pastures for much of their livelihood and that they need to give considerably more attention to pasture maintenance and improvement. From the standpoint of conservation, of a balanced agriculture, and of profits in an area such as this, the proper care of pastures is as important as the production of winter feeds. Pasturage cannot be expected to be perpetually abundant if the plant food elements in the soil are marketed through generations of livestock or washed away with no return of these elements to maintain fertility.

\section{TYPE OF FARMING AND FARM ORGANIZATION}

In planning adjustment programs for an area or a region, familiarity with current farming practices and with the condition of the soil resources on all groups of farms is essential. In addition to a general knowledge of the dominant nature of the adjustment problems it is also necessary to know to what extent these problems are similar on different groups of farms and between different parts of the area in order that the program may be broad enough in its scope and sufficiently flexible in its provisions to meet the most urgent needs of all farmers.

Groups of farms situated in Upshur, Harrison, Braxton, and Lewis Counties in the north-central area have been studied in considerable detail during the period 1933 to 1940. Farming conditions in these counties are typical of those in much of the state and particularly in the north-central area. For closer study of the resources, organization, and adjustment problems, farms for which farm business survey records were available 
were grouped into eight type-of-farming groups-beef, dairy. poultry, cash-crop, general, self-sufficing, and part-time (Table $3)$. The general, self-sufficing, and part-time groups were the largest in each county. Together these three groups included from 64 to 88 percent of the farms in each of the surveys and 81 percent of the 768 farms in the four counties. Self-sufficing farms alone comprised 34 percent of the total. Beef-cattle farms ranked next to these three groups in importance. Dairy, poultry, sheep, and cash-crop farms are not found in relatively large numbers.

These sample groups of farms were fairly representative of all farms in the four counties from the standpoint of distribution by type of farming. For comparison, the distribution by type of all farms in each of the four counties in 1929, as reported by the Census Bureau, is shown in Table 4 . Selfsufficing, general, and part-time farms together included from 61 to 79 percent of all farms in each county and 72 percent of all farms in the four counties in 1929. Self-sufficing farms alone included 35 percent of all farms.

Table 3-Distribution of Farms Surveyed in Specified Years in Braxton, Lewis, Harrison, and Upshur Counties Showing Number and Percentage of Farms in Each Type-of-Farming Group.

\begin{tabular}{|c|c|c|c|c|c|c|c|c|c|c|c|c|}
\hline \multirow{3}{*}{ Туре } & \multicolumn{12}{|c|}{ County and date of survey } \\
\hline & \multicolumn{2}{|c|}{$\begin{array}{c}\text { Braxton } \\
1933-34\end{array}$} & \multicolumn{2}{|c|}{$\begin{array}{c}\text { Braxton } \\
1935-36\end{array}$} & \multicolumn{2}{|c|}{$\begin{array}{r}\text { Lewis } \\
1933-34\end{array}$} & \multicolumn{2}{|c|}{$\begin{array}{c}\text { Lewis } \\
\mathbf{1 9 3 4 - 3 5}\end{array}$} & \multicolumn{2}{|c|}{$\begin{array}{l}\text { Upshur } \\
1937-38\end{array}$} & \multicolumn{2}{|c|}{$\begin{array}{c}\text { Harrison } \\
1937-38 \\
\end{array}$} \\
\hline & Num- & $\begin{array}{l}\text { Per- } \\
\text { cent }\end{array}$ & $\begin{array}{c}\text { Num- } \\
\text { ber }\end{array}$ & $\begin{array}{l}\text { Per- } \\
\text { cent }\end{array}$ & $\begin{array}{c}\text { Num- } \\
\text { ber }\end{array}$ & $\begin{array}{l}\text { Per- } \\
\text { cent }\end{array}$ & $\begin{array}{c}\text { Num- } \\
\text { ber }\end{array}$ & $\begin{array}{l}\text { Per- } \\
\text { cent }\end{array}$ & $\begin{array}{c}\text { Num- } \\
\text { ber }\end{array}$ & $\begin{array}{l}\text { Per- } \\
\text { cent }\end{array}$ & $\begin{array}{c}\text { Num- } \\
\text { ber }\end{array}$ & $\begin{array}{l}\text { Per- } \\
\text { cent }\end{array}$ \\
\hline Beef & 24 & $24^{\circ}$ & 6 & 5.3 & 10 & 16.9 & 27 & 13.5 & 13 & 12.4 & 56 & 28.7 \\
\hline & 2 & & 7 & & 5 & & 13 & & 7 & & 11 & 5.6 \\
\hline & & & & & 2 & 3.4 & 9 & 4.5 & . & & & \\
\hline $\begin{array}{l}\text { Shee } \\
\text { Cash }\end{array}$ & $\begin{array}{l}3 \\
3\end{array}$ & $\begin{array}{l}3.1 \\
3.1\end{array}$ & & & 2 & 3.4 & 2 & 10 & $\cdots$ & $\therefore$ & . & $\cdots$ \\
\hline Genera & 15 & 15.5 & 16 & 14.3 & $1 \overrightarrow{5}$ & 25.4 & 43 & 21.5 & $\ddot{2} \dot{9}$ & 27.6 & 92 & 47.2 \\
\hline $\begin{array}{l}\text { Self- } \\
\text { Suffi }\end{array}$ & & & 60 & & 15 & & 73 & 36 & 33 & & 36 & 18.5 \\
\hline Part-Time & 5 & 5.1 & 23 & 20.5 & 8 & 13.6 & 33 & 16.5 & $\Sigma 3$ & 21.9 & & \\
\hline Totals & 97 & & 112 & & 59 & & 200 & & 105 & & 195 & \\
\hline
\end{tabular}

Table 4-Percentage Distribution of All Farms in Upshur, Harrison, Lewis, and Braxton Counties, in 1929, by Type of Farm

\begin{tabular}{|c|c|c|c|c|c|}
\hline $\begin{array}{l}\text { Type of } \\
\text { farm }\end{array}$ & Upshur & Harrison & Lewis & Braxton & $\begin{array}{l}\text { Four } \\
\text { counties }\end{array}$ \\
\hline & $\begin{array}{c}\text { percent } \\
10.3\end{array}$ & $\begin{array}{c}\text { percent } \\
14.4\end{array}$ & $\begin{array}{c}\text { percent } \\
5.6\end{array}$ & $\begin{array}{c}\text { percent } \\
11.3\end{array}$ & $\begin{array}{l}\text { percent } \\
10.3\end{array}$ \\
\hline $\begin{array}{l}\text { Animal specialty } \\
\text { Dairy }\end{array}$ & $\begin{array}{c}10.3 \\
1.1\end{array}$ & $\begin{array}{r}14.4 \\
3.5\end{array}$ & $\begin{array}{l}5.6 \\
2.0\end{array}$ & $\begin{array}{r}11.3 \\
8.7\end{array}$ & $\begin{array}{r}10.3 \\
3.8\end{array}$ \\
\hline Poultry & 1.5 & 2.6 & 2.1 & 2.4 & 2.1 \\
\hline Fruit & 0.1 & 0.6 & 0.3 & 1.1 & 0.5 \\
\hline Truck & & 0.1 & & 0.6 & 0.2 \\
\hline General & 16.7 & 16.6 & 17.7 & 24.1 & 18.8 \\
\hline Self-sufficing & 44.4 & 27.0 & 40.8 & 25.8 & 35.2 \\
\hline Part-time & 16.3 & 17.8 & 20.3 & 19.1 & 18.2 \\
\hline All other & 9.6 & 17.4 & 11.2 & 6.9 & 10.9 \\
\hline
\end{tabular}




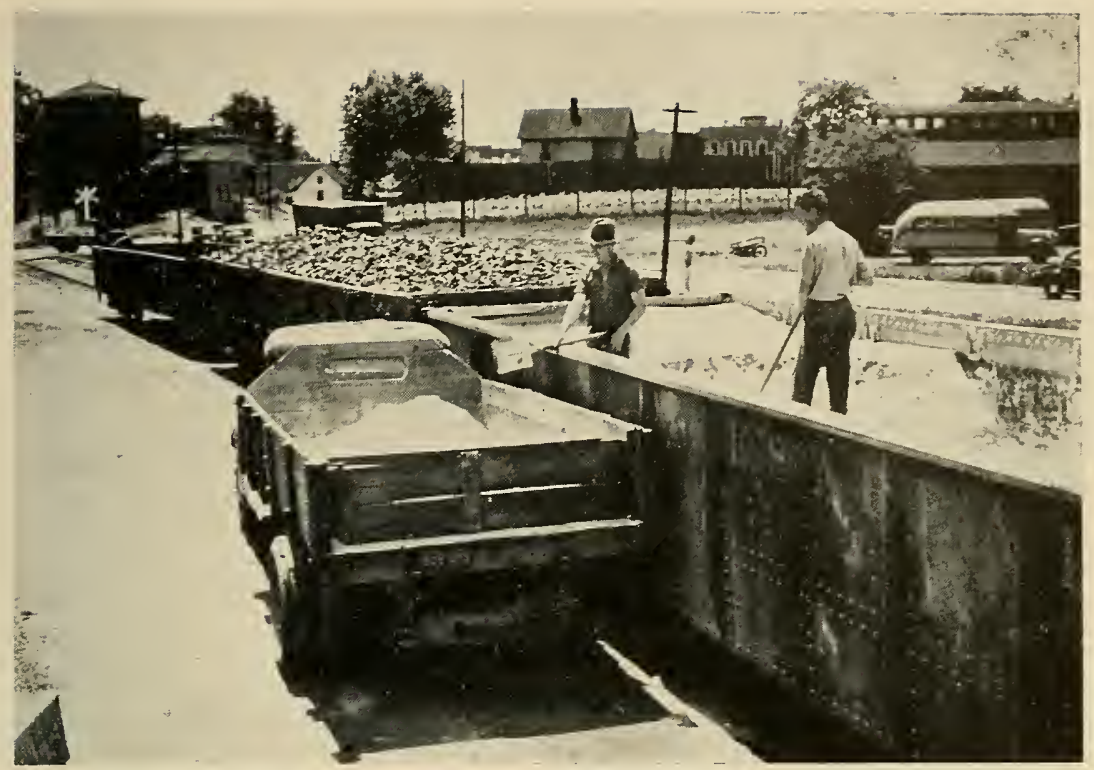

Fig. 2-Unlcading ground limestone at Buckhannon for use in connection with the Agricultural Conservation Program

\section{Specialized Types}

\section{Beef Farms}

Beef farms were those on which 40 percent or more of the total receipts was derived from the beef-cattle enterprise. These were more highly specialized than any other type of farm studied in the four-county area. Also the size of business was, in general, much larger than on other types of farms. A comparison of the figures presented in Table 5 with those for other types of farms will show that beef farms averaged larger in area, in acres in crops, in capital investment, and in total receipts than any of the other type groups.

Table 5-Average Size and Organization of Groups of Beef Farms in Braxton, Lewis, Upshur, and Harrison Counties

\begin{tabular}{|c|c|c|c|c|c|c|}
\hline \multirow[b]{2}{*}{ Items } & \multicolumn{6}{|c|}{ County and date of study } \\
\hline & $\begin{array}{c}\text { Braxton } \\
1933-34\end{array}$ & $\begin{array}{c}\text { Braxton } \\
1935-36\end{array}$ & $\begin{array}{r}\text { Lewis } \\
1933-34\end{array}$ & \begin{tabular}{|c|} 
Lewis \\
$1934-35$
\end{tabular} & $\begin{array}{l}\text { Upshur } \\
1937-38\end{array}$ & $\begin{array}{c}\text { Harrison } \\
1937-38\end{array}$ \\
\hline Total number of farms & 24 & 6 & 10 & 27 & 13 & 56 \\
\hline Acres in farm & 278 & 242 & 445 & 305 & 195 & 450 \\
\hline Acres in crops & 41 & 44 & 43 & 40 & $\begin{array}{r}130 \\
39\end{array}$ & 55 \\
\hline Number of animal units & 40 & 37 & 46 & & & \\
\hline Farm capital, dollars & 8,260 & 6,270 & 13,087 & 16,587 & 11,275 & 24,558 \\
\hline Farm cash receipts, dollars & 830 & 1,304 & 1,321 & 1,895 & 1,828 & 6,756 \\
\hline Percentage of farm receipts & on: & & & & & \\
\hline Crops & $\begin{array}{r}3.0 \\
82.6\end{array}$ & -2.2 & 8.2 .2 & 78.0 & $\begin{array}{l}10.5 \\
78.9\end{array}$ & $\begin{array}{r}0.9 \\
90.9\end{array}$ \\
\hline Livestock products & $\begin{array}{l}02.0 \\
13.6\end{array}$ & 19.0 & & 15. & 8 & 3.7 \\
\hline Miscella neous & 0.8 & 2.0 & 5.2 & 3.7 & 1.8 & 4.5 \\
\hline
\end{tabular}


From 77 to 91 percent of the total cash receipts on beef farms came from sales of livestock, principally beef cattle. Receipts from crop sales were negligible except in Upshur County, and percentages of total receipts from livestock products were lower than on farms in any other type-of-farming group (Table 5).

This type of business is more extensive in nature than many other types of farming and therefore usually involves farms with fairly large acreages and with a considerable percentage of the total land area in pasture. The highest incomes are usually associated with reasonably large farms operated fairly intensively. That is, these farms show a high pasture load and a high crop index. Most livestock gains are made on pastures. Farms requiring large acreages of pasture per animal unit indicate usually that the pasture is of poor quality and low productivity. It also means a considerable reduction in the number of animal units that a given pasture acreage will maintain.

The provisions of the state agricultural conservation program have resulted in considerable improvement in the rates of production and in the quality of forage crops on many beefcattle farms. Opportunities for the improvement of pastures are also present but have not been taken advantage of to as great an extent as they should for efficient production on most beef farms. Also the type of animal produced has an important bearing on income on beef farms, both from the standpoint of economical gains and of prices obtained.

\section{Dairy Farms}

There were 45 farms from which records were obtained that were classified as dairy farms. These farms varied considerably in acreage, capital investment, and number of cows. The acreage in crops and the total animal units per farm did not differ widely. Although dairying was the major enterprise on all farms, there was more diversity in the organization of some farms than of others, principally the result of the inclusion of additional livestock enterprises. Average figures for dairy farms in the various studies made in the four representative counties are shown in Table 6 .

The larger dairy farms were the more highly specialized, with larger dairy herds, and a higher percentage of the total receipts coming from sales of livestock products. There was apparent also a decided relationship between size of business and total net returns. On the dairy farms in the several studies the receipts from livestock products, chiefly milk and milk products, comprised from 47 to 85 percent of all cash receipts. Receipts from the sales of crops were small on all farms, most 
Table 6-Average Size and Organization of Groups of Dairy Farms in Braxton, Lewis, Upshur, and Harrison Counties

\begin{tabular}{|c|c|c|c|c|c|c|}
\hline \multirow[b]{2}{*}{ Items } & \multicolumn{6}{|c|}{ County and date of study } \\
\hline & $\begin{array}{c}\text { Braxton } \\
1933-34\end{array}$ & $\begin{array}{c}\text { Braxton } \\
1935-36\end{array}$ & $\begin{array}{r}\text { Lewis } \\
1933-34\end{array}$ & $\begin{array}{r}\text { Lewis } \\
1934-35\end{array}$ & $\begin{array}{l}\text { Upshur } \\
1937-38\end{array}$ & $\mid \begin{array}{c}\text { Harrison } \\
1937-38\end{array}$ \\
\hline Total number of farms & 2 & 7 & 5 & 13 & 7 & 11 \\
\hline Acres in farm & 121 & 141 & 229 & 193 & 181 & 145 \\
\hline Acres in crops & 24 & 35 & 29 & 36 & 33 & 31 \\
\hline Number of animal units & 27 & 16 & 25 & 35 & 26 & 25 \\
\hline Farm capital, dollars & 4,612 & 3,805 & 9,434 & 11,645 & 11,556 & 11,476 \\
\hline Farm cash receipts, dollars & 599 & 707 & 1,507 & 2,374 & 1,474 & 2,782 \\
\hline Percentage of farm receipts & from: & & & & & \\
\hline $\begin{array}{l}\text { Crops } \\
\text { Livestock }\end{array}$ & $\begin{array}{r}6.8 \\
28.9\end{array}$ & $\begin{array}{r}2.9 \\
48.9\end{array}$ & 1.9 & $\begin{array}{r}5.0 \\
2.8\end{array}$ & $\begin{array}{r}0.2 \\
27.1\end{array}$ & $\begin{array}{r}1.6 \\
11.8\end{array}$ \\
\hline Livestock products & 61.5 & 47.0 & 85.3 & 70.8 & 66.6 & $\begin{array}{l}11.8 \\
84.5\end{array}$ \\
\hline Miscellaneous & 2.8 & 1.2 & 2.2 & 1.4 & 6.1 & 2.1 \\
\hline
\end{tabular}

of the cash income being derived from livestock and livestock products.

A high crop index, efficient pasture utilization, and animals with high productive capacity are factors definitely associated with profits on dairy farms. The provisions of the Agricultural Conservation Program are admirably suited to aid in bringing about improvement in the first two of these factors, and dairy farmers were among the first to take advantage of some of the opportunities offered.

\section{Non-Specialized Types}

\section{Self-Sufficing Farms}

It has been pointed out that, numerically, self-sufficing farms outrank any other type of farm in each or all of the counties studied. This statement could also be made relative to 43 of the 55 counties in the state; or it could be applied to the state as a whole. In 1930, 39 percent of all farms in West Virginia were classified as self-sufficing. Of these 32,622 selfsufficing farms, 73 percent were of less than 100 acres. These figures indicate the extent of the low-income farm problem in the state. They also show that the problem is not confined to any one county or region but that it is quite general throughout the state.

There were 262 self-sufficing farms from which farm business records were obtained in the four-county area. A brief summary of some of the more significant factors relating to these farms is presented in Table 7 . The average figures included in the table show the similarity of the self-sufficing farms in many respects. The size of farm, acres in crops, animal units per farm, and total farm receipts were much the same in all of the studies. Differences in capital investment may be explained largely by differences in land values.

The percentages of total cash receipts from various farm sources also show the similarity of these self-sufficing farms in respect to the enterprises from which the major portion of 
Table 7-Average Size and Organization of Groups of Self-Sufficing Farms in Braxton, Lewis, Upshur, and Harrison Counties

\begin{tabular}{|c|c|c|c|c|c|c|}
\hline \multirow[b]{2}{*}{ Items } & \multicolumn{6}{|c|}{ County and date of study } \\
\hline & $\begin{array}{l}\text { Braxton } \\
1933-34\end{array}$ & $\left|\begin{array}{c}\text { Braxton } \\
1935-36\end{array}\right|$ & $\begin{array}{c}\text { Lewis } \\
1933-34\end{array}$ & $\begin{array}{c}\text { Lewis } \\
1935-36\end{array}$ & $\begin{array}{l}\text { Upshur } \\
1937-38\end{array}$ & $\begin{array}{c}\text { Harrison } \\
1937-38\end{array}$ \\
\hline Total number of farms & 45 & 60 & 15 & 73 & 33 & 36 \\
\hline Size of farm & 122 & 79 & 62 & 94 & 62 & 72 \\
\hline Acres in crops & 22 & 17 & 15 & 14 & 16 & 18 \\
\hline Number of animal units & 11 & 6 & 8 & 8 & 5 & 7 \\
\hline Farm capital, dollars & 2,592 & 2,097 & 2,564 & 4,033 & 2,415 & 4,463 \\
\hline Farm cash receipts, dollars & 205 & 188 & 169 & 176 & 183 & 313 \\
\hline \multicolumn{7}{|c|}{ Percentage of farm receipts from: } \\
\hline Crops & 5.1 & 12.3 & 4.4 & 0.7 & 6.7 & 16.8 \\
\hline Livestock & 55.9 & 47.5 & 36.6 & 49.4 & 54.2 & 46.7 \\
\hline Livestock products & 35.6 & 31.4 & 37.7 & 38.8 & 31.8 & 25.5 \\
\hline Miscellaneous & 3.4 & 8.8 & 21.3 & 11.1 & 7.3 & 11.0 \\
\hline
\end{tabular}

the cash income was derived. Receipts from the sales of livestock and livestock products comprised from 74 to 91 percent of total cash receipts. Receipts from the sale of crops in general were of minor importance. Livestock enterprises were clearly the important ones on the self-sufficing farms in this area. They were not, however, of sufficient size to provide incomes which would permit classification of the farms in any other type-of-farming group. Apparently, self-sufficing farmers were carrying on some of the more extensive types of farm enterprises on small farms with limited areas of both crop and pasture land.

Farm Family Living: One basic source of income on any farm is the contribution the farm makes toward family living in the way of home-grown products. This is often a substantial item in the consideration of total income. On farms where cash incomes are smail, the contribution of the farm toward family living looms larger in fundamental importance if not in amount. Data on the value of products furnished toward family living on the farms studied are incomplete. However, figures from farms in similar areas in West Virginia show that the average family (of 4.8 persons) used home-grown food and fuel valued at $\$ 476$. The per-capita value of food and fuel furnished by the farm was as follows:

Family of 3 persons-\$155 per capita

Family of 4.6 persons- 106 per capita

Family of 6.3 persons- 81 per capita*

The farmer can always utilize some of his time, labor, and productive facilities to provide a portion of the food requirements for his family. It is apparent that the importance of this phase of the farming activity will vary with factors such as size of family, and the commercial importance (size) and profitableness of the farm enterprises.

This brief statement on farm family living is included under the discussion of self-sufficing farms because of the greater relative significance the basic income has on farms of this type.

*The Family Living Derived from the Farm, by R. H. Fletcher. W. Va. Agricultural Experiment Station Mimeo. Cir. 31, pp. 62 and 68. 


\section{General Farms}

General farms were somewhat larger than self-sufficing farms, with larger capital investment and larger average receipts. No single enterprise on this group of farms yielded as much as 40 percent of the total receipts. The percentages of receipts from the sales of crops were higher on general farms than on any of the other type groups, particularly in Harrison and Upshur Counties. However, as may be seen from an examination of the figures in Table 8 , sales of livestock and livestock products accounted for from 70 to 88 percent of the total cash income. There were usually several livestock enterprises on the general farms, no one of which was sufficiently outstanding to permit classifying the farm in a more specialized group. The principal livestock products sold were milk, cream, butter, eggs and wool.

Table 8-Average Size and Organization of Groups of General Farms in Braxton, Lewis, Upshur, and Harrison Counties

\begin{tabular}{l|r|r|r|r|r|r}
\hline \hline \multirow{2}{*}{ Items } & \multicolumn{6}{c}{ County and date of study } \\
\cline { 2 - 8 } & $\begin{array}{c}\text { Braxton } \\
1933-34\end{array}$ & $\begin{array}{c}\text { Braxton } \\
1935-36\end{array}$ & $\begin{array}{c}\text { Lewis } \\
1933-34\end{array}$ & $\begin{array}{c}\text { Lewis } \\
1934-35\end{array}$ & $\begin{array}{c}\text { Upshur } \\
1937-38\end{array}$ & Harrison \\
$1937-38$ \\
\hline Number of farms
\end{tabular}

The general farms were characterized by greater diversity in organization than the other type-of-farming groups. None the less it can be readily appreciated that pastures were one of the chief factors, as the various livestock enterprises were depended upon by general farms to yield the major part of the farm income.

\section{Part-Time Farms}

In size and organization, part-time farms in this area were quite similar to self-sufficing farms. The farms were small with comparatively low capital investment and served primarily as a home and a supplementary source of income. The major portion of the income of operators of part-time farms came from some regular or part-time employment off the farms. Comparative figures for part-time farms included in the several surveys are shown in Table 9.

These farms sold some crops and obtained some income from miscellaneous sources, but from 80 to 91 percent of the cash income came from sales of livestock and livestock products. In general, these enterprises were small and quite diversified. 
Table 9-Size and Organization of Groups of Part-Time Farms in Braxton, Lewis, Upshur, and Harrison Counties

\begin{tabular}{|c|c|c|c|c|c|c|}
\hline \multirow[b]{2}{*}{ Items } & \multicolumn{6}{|c|}{ County and date of study } \\
\hline & $\begin{array}{l}\text { Braxton } \\
1933-34\end{array}$ & $\begin{array}{c}\text { Braxton } \\
1935-36\end{array}$ & $\begin{array}{c}\text { Lewis } \\
1933-34\end{array}$ & $\begin{array}{r}\text { Lewis } \\
1934-35\end{array}$ & $\begin{array}{l}\text { Upshur } \\
1937-38\end{array}$ & $\mid \begin{array}{c}\text { Harrison } \\
1937-38\end{array}$ \\
\hline Number of farms & 5 & 23 & 8 & 33 & 23 & 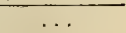 \\
\hline Size of farm & 92 & 79 & 128 & 114 & 94 & \\
\hline Acres in crops & 21 & 24 & 18 & 18 & 16 & \\
\hline Number of animal units & 12 & $\begin{array}{r}27 \\
9\end{array}$ & 12 & 13 & 6 & \\
\hline Farm capital, dollars & 4,498 & 2,884 & 5,519 & 6,247 & 3,006 & \\
\hline Farm cash receipts, dollars & 229 & 310 & 236 & 389 & 284 & \\
\hline Percentage of farm receipts & from: & & & & & \\
\hline Crops & 3.5 & 9.7 & & 7.1 & & ‥ \\
\hline Livestock & 25.6 & 64.5 & 52.2 & 47.1 & & $\cdots$ \\
\hline $\begin{array}{l}\text { Livestock products } \\
\text { Miscellaneous }\end{array}$ & $\begin{array}{l}54.6 \\
16.3\end{array}$ & $\begin{array}{r}22.7 \\
3.1\end{array}$ & $\begin{array}{c}39.4 \\
0.4\end{array}$ & $\begin{array}{l}34.5 \\
11.3\end{array}$ & $\begin{array}{r}39.9 \\
3.6\end{array}$ & $\cdots$ \\
\hline
\end{tabular}

The family living obtained from the farm and the income from various farm enterprises contributed to family welfare. These farms were not operated as efficiently nor were the productive resources utilized as intensively as would have been the case had the farm families been entirely dependent upon the farms for their incomes.

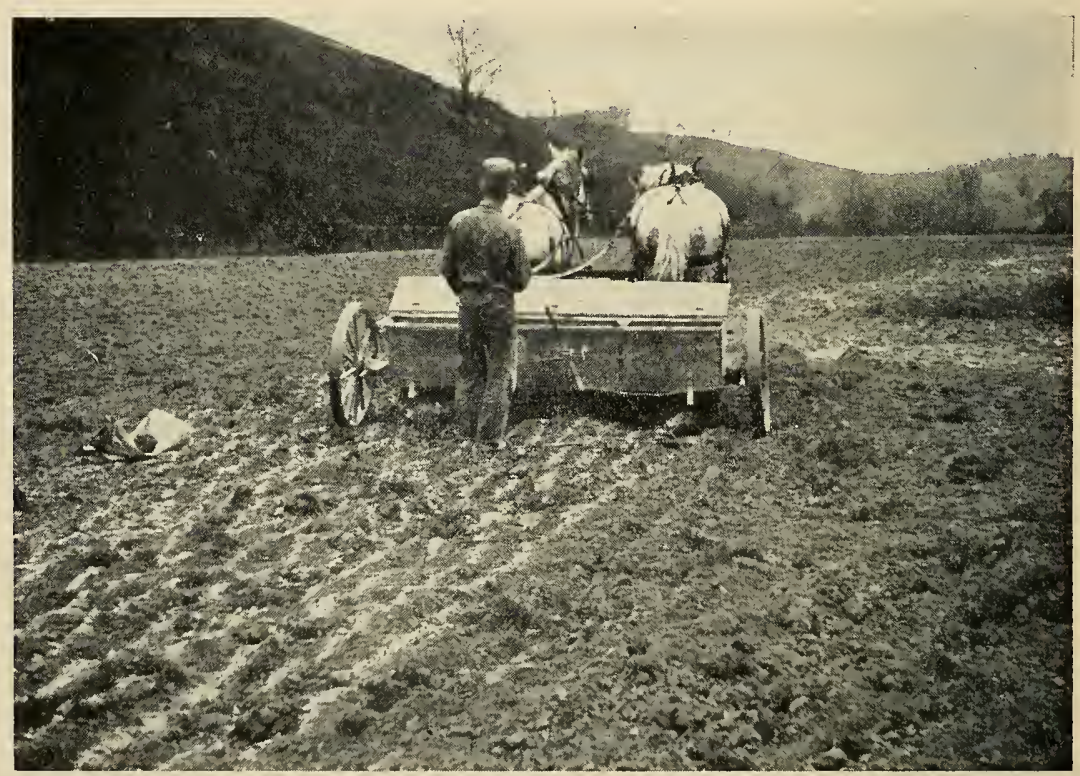

Fig. 3-Spreading burnt lime obtained in lieu of cash payment

The average non-farm receipts per farm on the part-time farms included in the study are shown in Table 10. 
Table 10-Receipts of Part-Time Farmers for Work off the Farm as Compared with Total Farm Receipts

\begin{tabular}{|c|c|c|c|}
\hline Area & $\begin{array}{c}\text { Number of } \\
\text { part-time } \\
\text { farms }\end{array}$ & $\begin{array}{l}\text { Total farm } \\
\text { receipts } \\
\text { per farm } \\
\end{array}$ & $\begin{array}{l}\text { Non-farm } \\
\text { income } \\
\text { per farm }\end{array}$ \\
\hline \multirow{5}{*}{$\begin{array}{l}\text { Braxton County } \\
\text { (97 farms) } \\
\text { Braxton County } \\
\text { (112 farms) } \\
\text { Lewis County } \\
\text { (59 farms) } \\
\text { Lewis county } \\
\text { (200 farms) } \\
\text { Upshur County } \\
\text { (105 farms) }\end{array}$} & 5 & $\$ 229$ & $\$ 666$ \\
\hline & 23 & 310 & 773 \\
\hline & 8 & 236 & 660 \\
\hline & 33 & 389 & 863 \\
\hline & 23 & 284 & 486 \\
\hline
\end{tabular}

\section{Livestock Enterprises Outstanding}

The foregoing discussion of the major type of farming groups indicates considerable similarity in farm organization within the groups and between counties. Any program designed to meet the major problems confronting farmers in any of these counties should be reasonably well adapted to all.

That these counties are part of a livestock-grazing area is clearly indicated by the fact that by far the larger part of the incomes on all of the outstanding farm types is obtained from sales of livestock and livestock products. Crop sales, in general are of minor importance, most of the crops grown being marketed indirectly through livestock. The role and importance of pastures in the area can hardly be overemphasized in view of the dependence placed on livestock production. Taking all farms in the surveys, the percentages of receipts from various major sources (Table 11) conclusively support the statement that the farming population in this area relies almost solely on livestock enterprises for cash income.

The presentation of an analysis of farm organization in this area from the standpoints of the most profitable combination of enterprises, the possibility of intensifying some phases of the farming business, the advisability of developing more cash-crop production, and other similar problems is not within the province of this discussion.

The chief difference between the counties which have been studied is the fact that two of them are somewhat "better agricultural counties" than the others. That is, because of markets, soils, topography, and transportation facilities, Lewis and Harrison Counties possess some agricultural advantages. There are fewer self-sufficing farms in these counties. 
Table 11-A Comparison of the Percentages of Total Cash Receipts Obtained from Various Farm Sources on All Farms Included in the Surveys

\begin{tabular}{|c|c|c|c|c|c|}
\hline \multirow{2}{*}{$\begin{array}{c}\text { County } \\
\text { and } \\
\text { date of survey }\end{array}$} & \multirow{2}{*}{$\begin{array}{l}\text { No. } \\
\text { of } \\
\text { farms }\end{array}$} & \multicolumn{4}{|c|}{ Percentages of total farm receipts from } \\
\hline & & Crops & Livestock & $\begin{array}{l}\text { Livestock } \\
\text { products }\end{array}$ & $\begin{array}{l}\text { Misc. } \\
\text { sources }\end{array}$ \\
\hline $\begin{array}{l}\text { Braxton } \\
1933-1934\end{array}$ & $94 \dagger$ & 4.7 & 69.3 & $22 . \overline{7}$ & 3.3 \\
\hline $\begin{array}{l}\text { Braxton } \\
\text { 1935-1936 } \\
\text { Lewis }\end{array}$ & 112 & 8.1 & 58.5 & 27.8 & 5.6 \\
\hline $\begin{array}{l}\text { Lewis } \\
1933-1934 \\
\text { Lewis }\end{array}$ & 59 & 7.7 & 53.8 & 34.2 & 4.3 \\
\hline $\begin{array}{l}1934-1935 \\
\text { Upshur }\end{array}$ & 200 & 5.5 & 46.9 & 43.3 & 4.3 \\
\hline $\begin{array}{l}1937-1938 \\
\text { Harrison }\end{array}$ & 105 & 13.0 & 54.8 & 27.6 & 4.6 \\
\hline $1937-1938$ & 195 & 4.1 & 77.9 & 13.0 & 5.0 \\
\hline
\end{tabular}

$\dagger$ Three specialized crop farms were omitted from this summary because they were decidedly "off type" farms for the area. One farm alone had receipts from crops which were twice as great as receipts from this source on all other farms combined.

A brief summary by type of farm ownership and tenure on the 768 farms from which records were obtained is presented in Table 12 . Only 6.5 percent of the farms were operated by tenants. The problem of the tenant farm is not a serious one.

Table 12 - Ownership and Tenancy on 768 Farms in Braxton, Lewis, Upshur, and Harrison Counties, by Type of Farm

\begin{tabular}{l|c|c|c}
\hline \multicolumn{1}{c}{$\begin{array}{c}\text { Type } \\
\text { of } \\
\text { farm }\end{array}$} & $\begin{array}{c}\text { Number } \\
\text { of } \\
\text { farms }\end{array}$ & $\begin{array}{c}\text { Number } \\
\text { of } \\
\text { owners }\end{array}$ & $\begin{array}{c}\text { Number } \\
\text { of } \\
\text { tenants }\end{array}$ \\
\hline Beef & 136 & 131 & 5 \\
Dairy & 45 & 44 & 1 \\
General & 210 & 197 & 13 \\
Part-time & 92 & 85 & 7 \\
Self-sufficing & 262 & 238 & 24 \\
All others & 23 & 23 & 0 \\
\hline Total & 768 & 718 & 50 \\
\hline
\end{tabular}

\section{FARM-ADJUSTMENT PROBLEMS IN THE AREA}

\section{The Pasture Problem}

The pasture problem is undoubtedly the outstanding problem in the north-central area and in livestock-grazing areas of the state. Some of the factors which have given rise to the present situation are:

1. Failure on the part of farmers to carry out pastureimprovement practices.

That farmers are not convinced of the value of pasture improvement is clearly indicated by the comparatively limited amounts of lime and fertilizer applied to pastures by cooperators in the Agricultural Conservation Programs to date. 
2. Progressive erosion on pasture areas, most of which are on rolling to steep land.

A thick stand of desirable pasture grasses cannot be maintained when the fertile topsoil is being lost. As the fertility level declines, the stand of grasses becomes thinner and the type of vegetation poorer.

3. Overgrazing.

Too intensive grazing has been a factor in pasture depletion. As pastures become poorer it takes an ever-increasing area to support an animal unit. If livestock numbers are maintained as pastures decline, the result is overgrazing, and a decline in quality of both livestock and pastures is inevitable.

4. Injury due to early and late grazing.

The number of farmers who leave cattle on pastures the year 'round is still too high. As an example, 206 of 278 farmers in the counties under discussion from whom records were obtained followed this practice.

5. Extended periods of drought.

Unusual weather conditions such as prevailed in 1930,1934 , and 1936 seriously affected pastures. The lower the fertility level of pastures at such times, the greater the injury and the slower the recovery.

In a pasture study made in 1935 , it was found that the acreage of pasture required per animal unit in Upshur and Lewis Counties was 5.3, and in Harrison County five acres were required. $\dagger$ Table 13 shows some of the details of conditions of pastures as revealed by the 1935 study.

Table 13-Condition of Pastures in Upshur, Lewis, and Harrison Countiesti

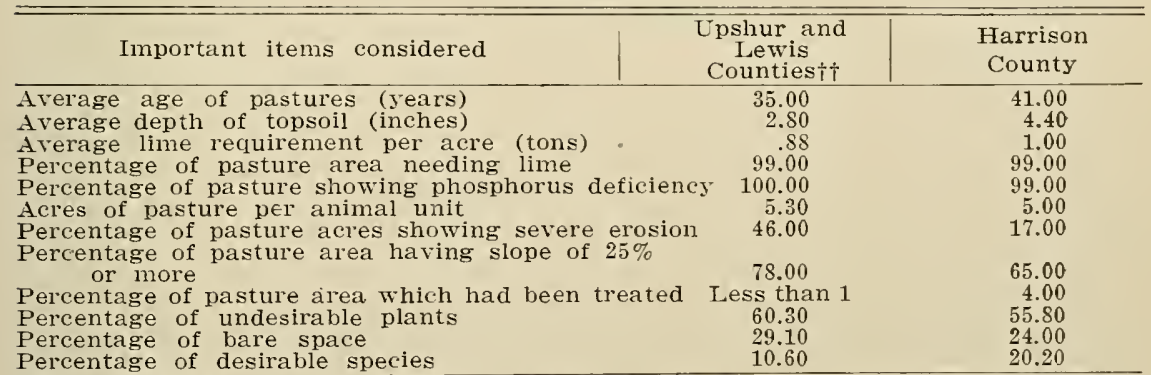

†TThese figures were compiled from a study of pastures in Ritchie, Upshur, and Lewis Counties.

$\div$ West Virginia Pastures, W. H. Pierre et al., W. Va. Agricultural Experiment Station Bul. 280. 
One conclusion drawn as a result of this study is that "even with the most favorable seasons, very little increase in desirable plants can be expected in most pastures unless something is done to improve the fertility of the soils." $\dagger$

Farmers recognize the fact that over a period of years the quality of pastures has declined. This was indicated by a study made in Lewis County in 1935. $\dagger$ A summary of estimates made by farmers of the condition of their pastures then as compared with the condition five, ten, and 25 years earlier is shown in Table 14.

Table 14-Condition of Pastures on Lewis County Farms in 1935 Expressed as a Percentage of Their Condition in 1930, 1925, and 1910

\begin{tabular}{c|c|c|c}
\hline $\begin{array}{c}\text { Base } \\
\text { year }\end{array}$ & $\begin{array}{c}\text { Percentage } \\
\text { basis }\end{array}$ & $\begin{array}{c}\text { Condition of pastures } \\
\text { in 1935 as percentage } \\
\text { of base year }\end{array}$ & $\begin{array}{c}\text { Number } \\
\text { reporting }\end{array}$ \\
\hline 1930 & 100 & 87.2 & 130 \\
1925 & 100 & 79.2 & 123 \\
1910 & 100 & 68.9 & 83 \\
\hline
\end{tabular}

For pastures to qualify in setting up the total farm allowance under the Agricultural Conservation Program, they must be capable of maintaining at least one animal unit on five acres. Pasture that will carry only one animal unit on each five acres is very ordinary pasture. Yet, according to their own estimates, farmers have considerable acreages of pasture which cannot qualify on this basis. The figures in Table 15 show the percentages of pasture which qualified on the foregoing basis in 1937 on sample groups of farms in Upshur and Lewis Counties. The samples were taken at random from each district in the counties. In Lewis County two separate samples were taken as a check on the sampling procedure.

The figures show that a fourth of the pasture in Upshur County in 1937 was too poor to support an animal unit on five acres. It should be noted also that open pasture in these counties constitutes a large percentage of the total land in farms.

Table 15-Percentages of Total Pasture Acreage Which Qualified in Setting Up Total Farm Allowance on Sample Groups of Farms in Upshur and Lewis Counties, 1937

\begin{tabular}{|c|c|c|c|c|c|}
\hline County & $\begin{array}{c}\text { Number } \\
\text { of } \\
\text { farms }\end{array}$ & $\begin{array}{c}\text { Total } \\
\text { acres } \\
\text { open } \\
\text { pasture }\end{array}$ & $\begin{array}{c}\text { Total } \\
\text { acres } \\
\text { pasture } \\
\text { qualifying }\end{array}$ & $\begin{array}{l}\text { Percent } \\
\text { of total } \\
\text { open } \\
\text { pasture } \\
\text { qualifying }\end{array}$ & $\begin{array}{l}\text { Percent } \\
\text { of total } \\
\text { acreage } \\
\text { in open } \\
\text { pasture }\end{array}$ \\
\hline $\begin{array}{l}\text { Upshur } \\
\text { Lewis }\end{array}$ & $\begin{array}{l}140 \\
125\end{array}$ & $\begin{array}{r}8,959.2 \\
16,429.2 \\
15819.5\end{array}$ & $\begin{array}{r}6,546.0 \\
14,481.4 \\
13.663 .5\end{array}$ & $\begin{array}{l}73.1 \\
88.1 \\
86.4\end{array}$ & $\begin{array}{l}58.9 \\
67.5 \\
67.9\end{array}$ \\
\hline
\end{tabular}

It seems reasonable to conclude that pastures are rapidly declining in quality in the north-central pasture area, and that farmers as a group realize this fact. They do not always take

†Op. cit. p. 50.

t+Labor Income on Lewis County Farms, by W. W. Armentrout. W. Va. Agricultural Experiment Station Mimeo. Cir. 16. 
into account all of the causes for this decline, as is indicated by the fact that 78 of the 200 Lewis County farmers in 1935 attributed to drought the decline in carrying capacity of pastures. If such opinion were widespread, it might help to explain the lack of effort toward pasture improvement. Drought has seriously affected pastures, but the blame for the present condition cannot be placed on this factor alone.

On the basis of the number of animal units pastured on the 768 farms surveyed, 5 acres of pasture were required per animal unit. It seems fair to conclude that this figure represents a reliable index of carrying capacity, although the data available do not indicate whether pastures were being utilized inefficiently, or to capacity, or were being overgrazed.

Efforts to remedy the situation or to check further decline in the quality of pastures have been limited. There must be general recognition of the fact that in areas such as this, pasture is the most valuable crop, and that it must receive the care and attention it deserves. The tendency has been for farmers to concentrate their improvement practices on cropland.

\section{The Balance Between Crop and Pasture Land}

Closely related to the pasture situation is the problem of a desirable balance between crop and pasture land. No definite ratio can be advocated because of variation in productivity of both crop and pasture lands. What the ratio should be would depend on both of these factors. In general, there should be sufficient cropland to provide opportunity to raise at least the necessary forage crops to winter the livestock which the pasture will support.

If farmers improve pastures, thereby increasing their quality and carrying capacities, the immediate result would be the possibility of producing better quality and finish or of increasing production of livestock normally carried. If livestock numbers are increased, attention should be paid to organization problems.

In the counties studied, on the basis of 1935 census figures, 17.6 percent of all farm land was in crops, 55 percent in open pasture, and 8 percent in woodland pasture. On the 768 farms surveyed, 17 percent of the land was in crops, 64 percent in open pasture, and 7.5 percent in woodland pasture.

The general tendency is for the percentage of the total farm area in pasture to increase as size of farm increases. However, within any size group there is a very wide variation explainable only in part by differences in carrying capacity of pastures or productivity of cropland. This statement is based on a study of 8,648 farms in the Agricultural Conservation Program in the four-county area in 1938 as well as on a study of those included in the surveys. It appears from all data avail- 
able that the question of balance between crop and pasture land merits attention in these areas. Sufficient investigational work has not yet been done to warrant definite conclusions or to form a basis for specific recommendations.

\section{The Low-Income Farm Problem}

Although the north-central area has been shown to be typically a livestock-grazing area, with from 60 to 70 percent of all farm land in open pasture, there are within the area, and generally throughout the state, many small self-sufficing farms. In any business venture the size of business is an important factor governing opportunities for profit. In an area such as this, characterized by the more extensive agricultural enterprises, total acreage in the farm is a fair index of the size of business.

A tabulation of 8,648 farms in the four counties in 1938 showed that 34 percent were farms of less than 50 acres. There was little variation between counties in the percentage of farms in this group. The farms included in the farm business surveys were considerably above average in size, yet of these $768 \mathrm{farms}$, 17 percent were in the group having less than 50 acres per farm.

These data indicate that the problem of the low-income farm is general throughout the entire north-central pasture area. It is true that in some sections low-income farms are much more numerous than in others, but there is no district which has been studied in any of the counties where the problem does not exist.

Most of the agricultural research work, extension activity, agricultural credit operations, organization of marketing agencies, etc. have centered largely about farms engaged in commercial production; in other words, the better farms. To date, the low-income farmers have benefited least of all groups from organized agencies, both state and federal, with two exceptions, namely, relief organizations and the Farm Security Administration.

Approximately 9,000 low-income farmers in West Virginia obtain financial assistance through relief agencies.* If lowincome farmers must be helped financially through relief or by other means, the immediate problem is to help them where they are. This means a need for shift in emphasis on the part of most of the agencies which can help in solving both the immediate and the long-time problems for this group.

The serious nature of the low-income farm problem from a sectional or state basis is now generally recognized, as indicated by the 1940 conference held in the state for the discussion of this problem.* What the solution is, or should be, remains to

*Proceedings of the 1940 Conference on Low-Income Farms. W. Va. Agricultural Experiment Station Bul. 299. 
be developed. With at least 39 percent of the farms of the state included within this group, some plan of action to meet their problems and improve their economic position is imperative from the viewpoint of the social, economic, and political welfare of the state.

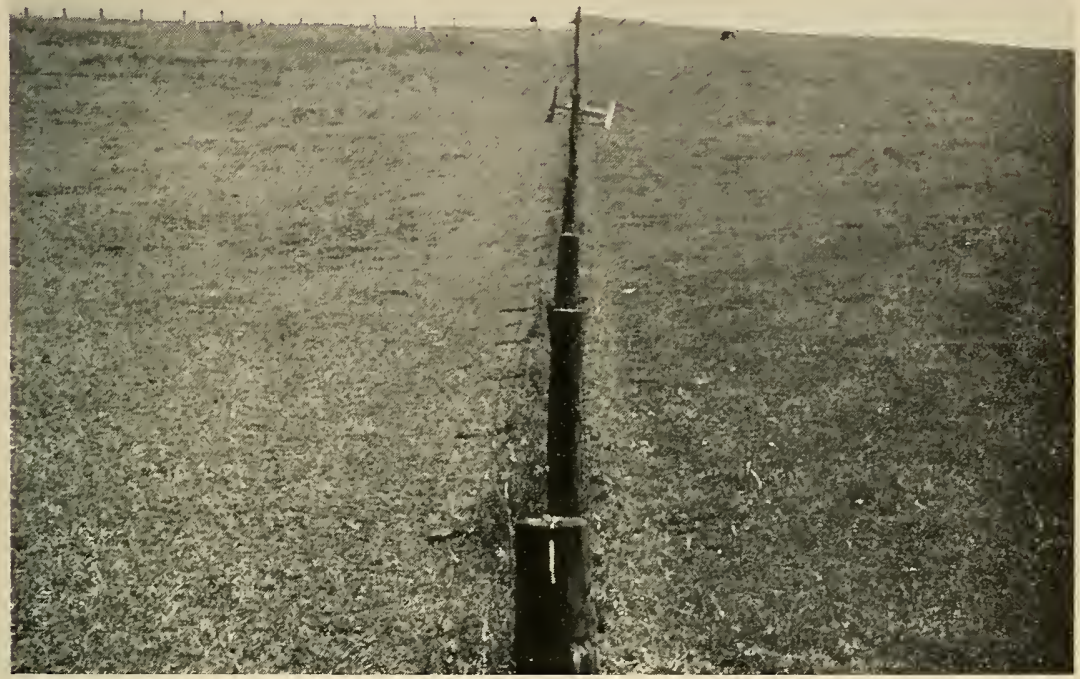

Fig. 4-What happens to a pasture under non-treatment and under treatment. The area on the left was not treated

\section{AGRICULTURAL CONSERVATION PROGRAMS}

In studying the organization of farms and the operation of the conservation programs, the foregoing problems must be kept in mind. The Agricultural Conservation Programs to date should be viewed in the light of what has been accomplished and how well such programs were and are adapted to the needs of all farms in the area, including the large group of low-income farms. Also, because of the topography and soils and the resultant predominance of open pasture, the accomplishments under the programs should be judged in part on the amount of conservation which has been brought about on pasture areas. There appears to be no greater opportunity to effect outstanding results in conservation than on the extensive acreages of pasture in a section such as the one under consideration. Livestock enterprises predominate. Most of the livestock gains are made on pasture. The value of these gains in weight and production above costs represents profits. There is a direct relationship between the quality of pastures and the economic welfare of the farming population. 
The programs should be viewed also from the standpoint of their adaptability to present systems of farming in the area, keeping in mind that the farmer's first concern is to make a living for himself and his family with the productive factors at his disposal.

\section{The State Programs}

The agricultural programs in effect in West Virginia from 1933 to 1936 were the special commodity programs covering wheat, corn, hogs, and tobacco. Although many farmers in West Virginia received payments under these programs, they were not so applicable to general state conditions, nor were they as flexible as the programs which have been carried out since 1936.

Diversion: The 1936 program carried a provision whereby farmers were encouraged to divert crop acreages from soildepleting to soil-conserving crops. The payments for diversion were fairly substantial and a large part of the payments to farmers for participation in the 1936 program was for diversion, This is indicated by the fact that money earned by diversion represented 59 percent of all payments in Upshur County and 61.4 percent of total payments to Lewis County farmers in 1936. Agricultural leaders familiar with West Virginia conditions felt rather strongly that farmers in the state should not be encouraged to divert, chiefly because the average soil-depleting base in most West Virginia counties was already very low. In 1936 the average soil-depleting base in Lewis County was 11.4 acres, and in Upshur County it was 10.7 acres.

Table 16 shows a distribution of all farms in the 1937 program in Upshur County on the basis of acreage in the soil-depleting base. Only about 8 percent of the farms had a base as large as 20 acres. Thus the opportunities to divert in this area are definitely limited.

Table 16-All Farms in the 1937 Agricultural Conservation Program in Upshur County Distributed According to Acres in Soil-Depleting Base

\begin{tabular}{cc||cc}
\hline $\begin{array}{c}\text { Acres of soil- } \\
\text { depleting base }\end{array}$ & $\begin{array}{c}\text { Number } \\
\text { of farms }\end{array}$ & $\begin{array}{c}\text { Acres of soil- } \\
\text { depleting base }\end{array}$ & $\begin{array}{c}\text { Number } \\
\text { of farms }\end{array}$ \\
\hline Less than 2 & 31 & $12.0-13.9$ & 130 \\
$2.0-3.9$ & 86 & $14.0-15.9$ & 91 \\
$4.0-5.9$ & 118 & $16.0-17.9$ & 53 \\
$6.0-7.9$ & 124 & $18.0-19.9$ & 27 \\
$8.0-9.9$ & 121 & $20.0-21.9$ & 38 \\
$10.0-11.9$ & 166 & 22 or more & 45 \\
\hline & & Total & 1,030 \\
\hline
\end{tabular}

A conservation program should be designed to fit as nearly as possible the farming conditions in the area to which it applies. Because of the variation in size and types of farms in most areas it is very difficult to develop a program that will be equally appealing and equally well adapted to all groups. In 
other words, any general program is almost sure to benefit some farm groups more than others.

A study of participation in the 1936 program in several of the north-central counties revealed that the average size of farm participating was considerably larger than the average for the county. When analyzed by size groups, the percentages of farms in those groups of more than 100 acres were much higher for participating farms than were the percentages of the total number of farms in the county which fell in these groups. At the outset, therefore, more of the larger farms were cooperating in the programs.

In general, the same thing could be said of participants in the 1937 program. For example, the average size of farm in Upshur County in 1935 was 73 acres. The average size of farm earning payment under the 1937 program was 105 acres. Naturally, as the number of farms cooperating increases, more of the smaller farms are drawn in and the difference in size is not so pronounced between all farms and participating farms. However, the larger farms seemed to find the programs of more direct benefit to them. There were 272 farms in Upshur County in 1937 which were listed but on which no payment was earned. The average size of farms not earning payment was 72 acres, while the size of those earning payment was 105 acres. Those farmers who earned no payment in 1937 were on smaller farms. The average size of farm earning payment in Lewis County in 1937 was 240 acres as compared with an average size of farm of 125 acres for all farms in the county.

Neither the General Program nor the Experimental Program in West Virginia has met the situation adequately for the small farmer. Both programs have tended to encourage the extensive type of enterprise in which most of the small farmers engage on a limited acreage. From the standpoint of helping to raise incomes on these farms the possibilities through the programs to date have been limited somewhat.

A provision was included in the 1940 program for increasing the total farm allowance on small farms to $\$ 20$. However, this amount had to be earned by approved practices carried out. On small farms the opportunities for earning substantial amounts through soil-conserving practices are limited. Fortyfive percent of all farms receiving payments in Upshur County in 1939 had gross earnings per farm under the program of $\$ 20$ or less. It has not been ascertained to what extent the 1940 increase in the maximum farm allowance on small farms resulted in increased earnings under the program.

\section{The Upshur County Experimental Program}

Upshur was one of nine counties in the United States in which there was established an experimental agricultural conservation program in 1938 . The county was chosen because it was 
typical of much of the pasture-grazing area in the state. Recognizing the importance of the pasture problem, the Upshur County A. C. P. committee recommended to fellow farmers and to the Agricultural Adjustment Administration that an experimental program designed primarily to encourage pasture improvement be established in that county. Details of the program were prepared, and the program was adopted by both the farmers and the A. A. A. in 1938. The experimental program was applicable only in Upshur County and was in operation during 1938, 1939, and 1940.

The experimental program deviated from the regional program at only a few strategic points. Thus these provisions could be tried out and if they proved practicable and successful they might later be incorporated into the state or regional program.

The outstanding feature of the experimental program was the requirement that a part of the practices comprising the soilbuilding goal for the farm be carried out on pasture. For each eight acres of fenced, non-crop, open pasture on the farm capable of supporting at least one animal unit on each five acres, it was required that one unit of soil-building practice be carried out on pasture if full farm allowance was to be earned. The number of units of pasture-improvement practices required per farm was not large and, as can be seen, varied directly with the area of qualifying pasture on the farm. It was thought, however, that if many farmers could be encouraged to conduct small demonstrations on their own farms, pastures would soon begin to receive the attention they merit. This requirement was in keeping with what was considered to be the outstanding farm problem in the area.

Also, in the experimental program the complementary practices of liming and the application of superphosphate were tied together. Payments for the application of superphosphate on pasture were made only if such land had been treated with lime within the same year or in the preceding five years. West Virginia soils are characteristically deficient in lime and in phosphorus. There is ample experimental evidence to show that neither of these materials alone will give the results on pastures in the state that can be obtained when both are used. This provision was therefore based on recommended practice. However, full credit for the application of lime anywhere on the farm could be obtained under the program.

Payment for seeding grasses and legumes was made only if the land seeded had been treated with lime within the same year or in the preceding five years and with superphosphate within the same or the preceding year. If lime was applied more than two years before seeding, tests must have shown that additional lime was not required. 
It is apparent that the special provisions of the experimental program centered largely around the use of lime and superphosphate. Therefore, arrangements were made at the outset whereby participating farmers could obtain lime and superphosphate as conservation materials in lieu of payment. This provision was simply a method of extending credit with future earnings under the program as security.

The supplying of materials in lieu of payment had several decided advantages:

1. It made possible fuller participation in the program.

2. Orders could be placed early to obtain delivery of materials when needed.

3. It removed the necessity of paying cash for materials at a time when so many farm operations demand cash outlays.

4. Materials could be obtained and applied when other demands for farm labor were not acute.

5. A large part of the benefit obtained through participation was applied directly to farm improvement.

Acreage allotments for soil-depleting crops which are characteristic of the regional programs were dispensed with in the Upshur county program. The soil-building practices were essentially the same as those in the state program.

In a survey of 181 farmers who had cooperated in the 1937 program the reason given by 78 for not earning their full farm allowance was that they didn't understand the program. It was felt, therefore, that special educational effort in connection with the experimental program would prove effective. Particular emphasis was placed on the educational phase during the time the experimental program was in operation. In 1940 , Upshur County farmers carried out 91 percent of the units in the soil-building goal. The state average was 80.9 percent, with 50 percent of the counties having a percentage below 80 . In this connection, it is of interest to note that the source of information on the program that was ranked first in importance by 280 farmers in the four counties, when these farmers were interviewed personally, was personal interviews with $\mathrm{A}$. C. P. workers. This would indicate that the plan to hold personal conferences and work out farm plans is sound if the farmers are to judge as to the method of obtaining information which is most helpful to them. Pamphlets and circular letters were ranked second by the farmers, and local meetings ranked third in importance as a source of information.

\section{Participation Maintained}

In spite of the fact that certain restrictions were placed in the experimental program which were not in the regular program, there is no evidence to indicate that those provisions 
discouraged participation. In general, the growth in participation in the four counties has been quite similar. In 1938, the first year in which the experimental program was in effect, there was a 46-percent increase in the number of participants in Upshur County (Table 17). In Harrison County the increase was 29 percent; in Lewis County, 34 percent; and in Braxton County, 78 percent. In 1937, when all counties operated under the regional program, the percentage increase over 1936 in the number of cooperators was lower in Upshur County than either of the other three. On the basis of the total number of farms in the counties in 1940, the number of farms making application for payment in 1939 represented 56 percent of all farms in Upshur County, 48 percent in Harrison County, 66 percent in Lewis County, and 48 percent in Braxton County. Under the 1940 program these percentages were 75 for Upshur County, 68 for Harrison County, 66 for Lewis County, and 54 for Braxton County.

Table 17-Number of Participants in the Agricultural Conservation Programs in Upshur, Harrison, Lewis, and Braxton Counties, 1936-1940

\begin{tabular}{l|r|r|r|r}
\hline \hline \multirow{3}{*}{ Year } & \multicolumn{4}{|c}{ County } \\
& Upshur & Harrison & Lewis & Braxton \\
\cline { 2 - 5 } & & 518 & 394 & 345 \\
1936 & 450 & 831 & 659 & 641 \\
1937 & 703 & 1,069 & 883 & 1,138 \\
1939 & 1,030 & 1,351 & 1,213 & 1,407 \\
1940 & 1,253 & 1,859 & 1,210 & 1,568 \\
\hline
\end{tabular}

The growth in the program in Upshur County in practices performed and in payments earned has been consistent with the growth in surrounding counties. Average payments per farm in Upshur County were lower than in other counties, but this was due largely to the fact that the average size of farm in Upshur County is smaller than in the other counties, and the percentage of self-sufficing farms is comparatively high. The percentage increase in earnings in Upshur County in 1938, 1939, and 1940 over the immediately preceding year was as great or greater than the percentage increases in the other counties, with a single exception of 1938 in Harrison County (Table 18).

Table 18-Total Soil-Building Payments* in Upshur, Harrison, Lewis, and Braxton Counties, 1936-1940

\begin{tabular}{l|c|c|c|c}
\hline \multirow{2}{*}{ Year } & \multicolumn{4}{|c}{ County } \\
\cline { 2 - 5 } & Lpshur & Harrison & Lewis & Braxton \\
\hline 1936 & $\$ 6,271$ & $\$ 9,322$ & $\$ 5,181$ & $\$ 5,268$ \\
1937 & 15,326 & 24,431 & 21,136 & 21,739 \\
1938 & 24,327 & 40,706 & 32,404 & 30,595 \\
1939 & $37,936 \dagger$ & $52,233 \dagger$ & $50,617 \dagger$ & $45,194 \dagger$ \\
1940 & $53,640 \dagger$ & $86,220 \dagger$ & $51,665 \dagger$ & $51,506 \dagger$ \\
\hline
\end{tabular}

* Payments for diversion not included.

$\dagger$ Estimated on basi's of total soil-building units accomplished plus small farm increases. 


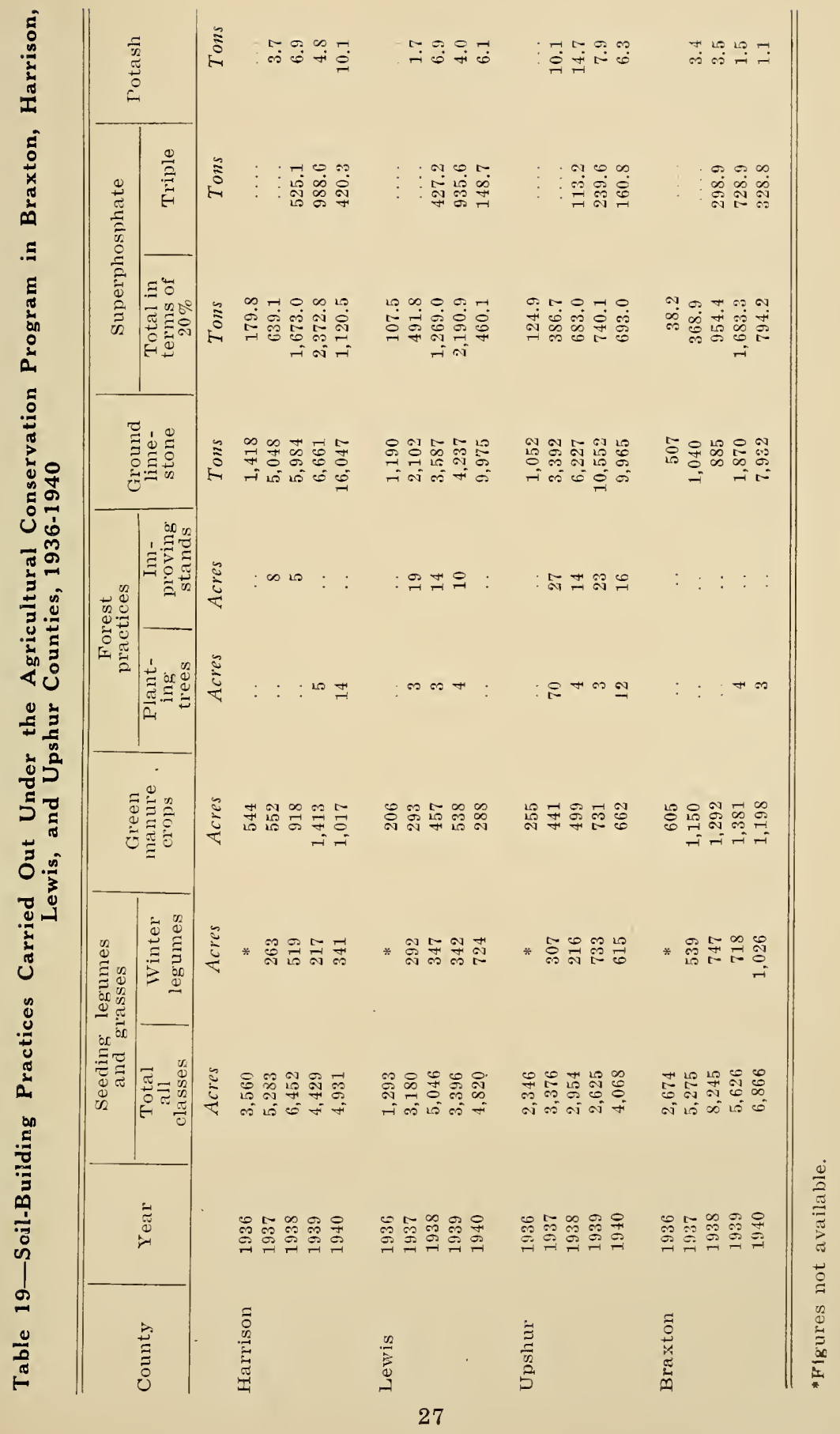


A summary of the soil-building practices carried out in the four-county area from 1936 to 1940 also shows that the growth under the operation of the experimental program in Upshur County compared favorably with that in adjacent counties (Table 19). Due to advancing of the closing date for the 1940 program, the figures for that year represent a 10-month period.

\section{Materials in Lieu of Payment}

Because of the emphasis on the use of lime and superphosphate in the experimental county program, arrangements were made in 1938 to supply both of these materials in lieu of payment in Upshur County. Upshur County obtained 2,162 tons of lime in lieu of payment in 1938. In 1939 this total was increased to 6,668 tons, or almost one-seventh of the total amount of lime obtained by the 24 counties through the Agricultural Adjustment Administration. In 1940 Upshur County received 8,547 tons of lime in lieu of payment. The total quantities of lime used in the four counties from 1937 to 1940 on a ground-limestone equivalent basis and the quantities obtained in lieu of payment are shown in Table 20.

Table 20-Lime Used by Participants in the Agricultural Conservation Program in Upshur, Harrison, Lewis, and Braxton Counties, 1937-1940

\begin{tabular}{|c|c|c|c|c|c|c|c|}
\hline \multirow{2}{*}{ County } & \multicolumn{4}{|c|}{$\begin{array}{l}\text { Total lime used on } \\
\text { cooperating farms (tons) }\end{array}$} & \multicolumn{3}{|c|}{$\begin{array}{l}\text { Tons of lime obtained } \\
\text { through A. A. A. }\end{array}$} \\
\hline & 1937 & 1938 & 1939 & 1940 & 1938 & 1939 & 1940 \\
\hline $\begin{array}{l}\text { Upshur } \\
\text { Harrison } \\
\text { Lewis } \\
\text { Braxton }\end{array}$ & $\begin{array}{l}3,392 \\
5,048 \\
2,102 \\
1,040\end{array}$ & $\begin{array}{r}6,227 \\
5,984 \\
3,586 \\
885\end{array}$ & $\begin{array}{r}10,552 \\
6,661 \\
4,237 \\
1,870\end{array}$ & $\begin{array}{r}9,965 \\
16,047 \\
9,975 \\
7,932\end{array}$ & $\begin{array}{c}2,162 \\
\ldots \\
\ldots \\
\ldots\end{array}$ & $\begin{array}{r}6,668 \\
871 \\
2,010 \\
1,027\end{array}$ & $\begin{array}{r}8,547 \\
11.844 \\
8.839 \\
7,372\end{array}$ \\
\hline
\end{tabular}

There is little doubt that the furnishing of materials greatiy stimulated the use of lime in Upshur County. The increases which took place in its use during 1938 and 1939 as compared with increases in surrounding counties during the same period were outstanding. The tying together of the use of lime and superphosphate in the experimental program may also have had much to do with the rapid increase in the use of lime in Upshur County. The experimental program endeavored to strike a desirable balance and to bring the farmers to the point of using lime and superphosphate together, or to lime the land first, applying superphosphate perhaps the next year. The use of superphosphate alone was greatly discouraged.

Upshur was the only county in the state in which both lime and superphosphate were supplied in lieu of payment in 1938 . These materials were made available on the same basis in 24 counties in 1939 (including Harrison, Lewis, and Braxton), in 32 counties in 1940, and in 39 counties in 1941. The marked 
increase in the use of lime in Harrison, Lewis, and Braxton Counties in 1940 can also be attributed largely to this provision. The supplying of materials in lieu of payment has undoubtedly been a significant factor in participation. The present "allmaterials" program is a direct outgrowth of the successful experience with this provision.

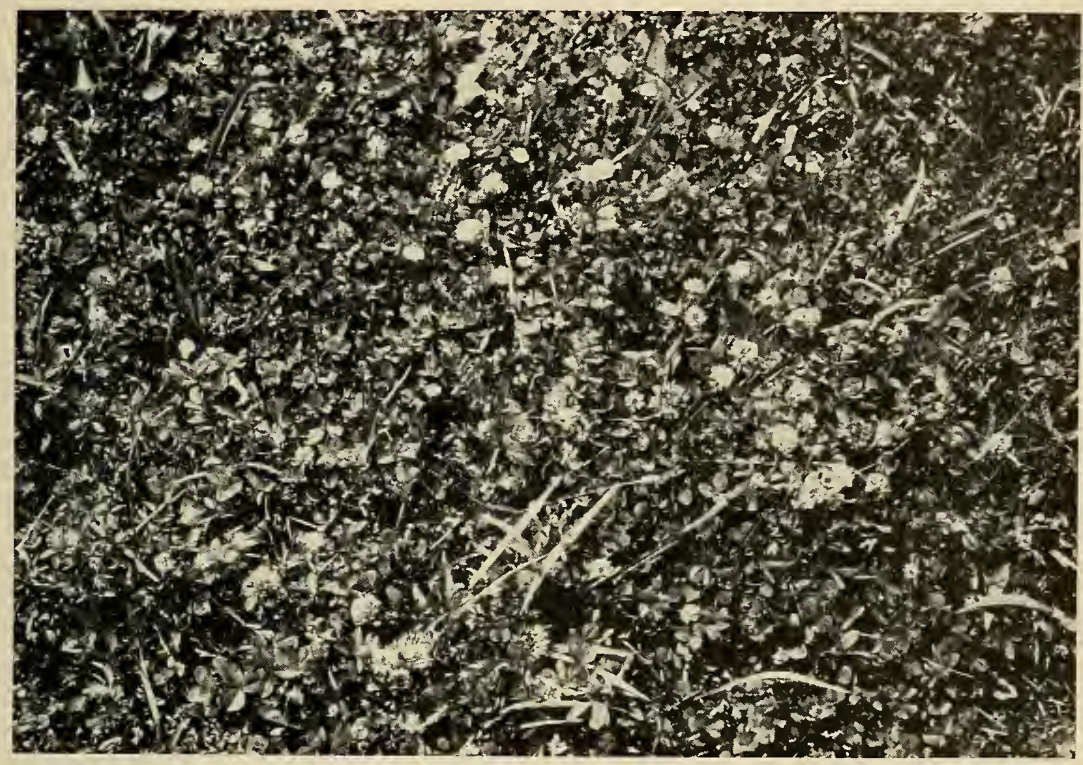

Fig. 5-Close-up of vegetation on pasture seen on right in Figure

4. This pasture was not reseeeded but simply treated with lime and superphosphate. Note the thick stand of clover two years after treatment

\section{Pasture Improvement}

It has been pointed out that pasture improvement was the outstanding consideration in formulating the experimental county program. Studies made of participation in the programs before 1938 had revealed that very few soil-building practices were being carried out on pastures in the north-central area. A survey of 280 farms in Upshur, Harrison, and Lewis Counties was made in 1938 to ascertain to what extent pasture had been improved in 1936, 1937, and 1938. (See Table 21.) Because of the fact that the experimental program in Upshur County was not approved until April, 1938, and lime contracts were not approved until June, most of the pasture improvement in that county in 1938 was done in August, September, and 
Table 21-Summary of Amount of Pasture-Improvement Work Done on 280 Farms in Harrison, Lewis, and Upshur Counties, 1936. $1937-1938$

\begin{tabular}{|c|c|c|c|c|c|c|c|c|}
\hline \multirow{2}{*}{ County } & \multirow{2}{*}{$\begin{array}{l}\text { Number } \\
\text { of } \\
\text { farmers } \\
\text { inter- } \\
\text { viewed }\end{array}$} & \multicolumn{3}{|c|}{$\begin{array}{l}\text { Number who have } \\
\text { done some pasture } \\
\text { improvement work* }\end{array}$} & \multicolumn{3}{|c|}{$\begin{array}{l}\text { Acres } \\
\text { treated }\end{array}$} & \multirow{2}{*}{$\begin{array}{c}\text { Total } \\
\text { pasture } \\
\text { acreage on } \\
\text { all farms } \\
\text { studied }\end{array}$} \\
\hline & & 1936 & 1937 & 1938 & 1936 & 1937 & 1938 & \\
\hline Harrison & 103 & 12 & 18 & 14 & 193 & 332 & 228 & 16,458 \\
\hline Lewis & 72 & 5 & 13 & 4 & $2 \frac{1}{2}$ & 136 & 13 & 8,468 \\
\hline Upshur & 105 & 8 & 18 & 23 & 53 & 76 & 87 & 6.420 \\
\hline Total & 280 & 25 & 49 & 41 & 270 & 544 & 328 & 31,346 \\
\hline
\end{tabular}

*Includes use of line and/or superphosphate, reseeding, contour furrowing.

October. The records were taken before this time, so that the figures in the table indicate the normal amount of voluntary pasture-improvement work done on the farms studied. The results in Upshur County were not greatly affected by the requirements of the experimental program for the reasons given. The survey showed rather conclusively that pastures had received and, in general, were receiving little attention by farmers. The data in the table show the comparatively few farmers who had done any pasture-improvement work and the limited acreage involved as compared with the total acreage of open pastures on these farms.

The pasture requirements in the Upshur County program in 1938 resulted in a total of 2,312 units of pasture-improvement practices. In other words, about one-sixth of all lime and one-eleventh of all superphosphate used under the 1938 program in that county went on pasture. Had not the supply of fertilizer furnished as conservation material become exhausted before the end of the year, and had all lime applied for been available, the foregoing figures would have been still higher. There were 253 farmers who improved some pasture in Upshur County under the 1938 program. Because of the factors mentioned, such as late approval of the program and lime contracts, and limited supplies of materials, the results obtained under the 1938 program in Upshur County as regards pasture improvement marked only the beginning (Table 22).

In $1939,5,797$ units of pasture-improvement work were carried out in Upshur County. This was $2 \frac{1}{2}$ times the total carried out under the first year of the experimental program. More than a thousand farmers in the county in 1939 did some pasture-improvement work. More than a fourth of the 10,552 tons of lime used in the county in 1939 went on pastures. The remarkable increase in pasture-improvement work in 1938, 1939, and 1940 in Upshur County, a county in which the amount of pasture-improvement work being done before that time was almost negligible, illustrated the effect of the pastureimprovement provision in the experimental program. The equivalents of 214 tons of 20 percent superphosphate and of 
2,931 tons of ground limestone were applied on Upshur County pastures by participants in the 1939 program (Table 22).

Pasture-improvement practices carried out under the experimental program showed further increase in 1940. As seen in Table 22, Upshur County farmers cooperating in the program in 1940 carried out $6,971.7$ units of soil-building practices on pastures. This represented an increase of 1,174 units over the 1939 total. Again, more than 1,000 farmers in the county carried out some pasture-improvement practices. Onefourth of all lime used on participating farms in the county in 1940 went on pastures and nearly one-third of all superphosphate was used in pasture improvement. There were 893 farmers in Upshur County who used lime on pastures in 1940 and 411 who applied superphosphate on pastures.

Table 22-Pasture Practices Carried Out in Upshur County, 1938-1939-1940

\begin{tabular}{|c|c|c|c|c|}
\hline Year & Materials & $\begin{array}{l}\text { Number } \\
\text { reporting }\end{array}$ & $\begin{array}{l}\text { Total units } \\
\text { carried out }\end{array}$ & $\begin{array}{l}\text { Tons } \\
\text { used }\end{array}$ \\
\hline 1938 & $\begin{array}{l}\text { Superphosphate } \\
20 \text { percent } \\
\text { Triple } \\
\text { Potash } \\
\text { Ground IImestone } \\
\text { Total units on pasture }\end{array}$ & $\begin{array}{r}54 \\
58 \\
3 \\
244\end{array}$ & $\begin{array}{r}208.8 \\
683.1 \\
2.1 \\
1,418.4 \\
2,312.4\end{array}$ & $\begin{array}{r}25.0 \\
34.1 \\
0.2 \\
1.063 .8 \\
\end{array}$ \\
\hline 1939 & $\begin{array}{l}\text { Superphosphate } \\
20 \text { percent } \\
\text { Triple } \\
\text { Potash } \\
\text { Ground limestone } \\
\text { Total units on pasture }\end{array}$ & $\begin{array}{r}76 \\
244 \\
4 \\
795 \\
\end{array}$ & $\begin{array}{r}188.2 \\
1,700.5 \\
0.4 \\
3,908.0 \\
5,797.1\end{array}$ & $\begin{array}{r}23 \\
85 \\
2.931 \\
\ldots \ldots\end{array}$ \\
\hline 1940 & $\begin{array}{l}\text { Superphosphate } \\
20 \text { percent } \\
\text { Triple } \\
\text { Potash } \\
\text { Ground limestone } \\
\text { Total units on pasture }\end{array}$ & $\begin{array}{r}188 \\
232 \\
12 \\
893 \\
\ldots\end{array}$ & $\begin{array}{r}709.4 \\
1,216.3 \\
4.4 \\
5,041.6 \\
6,971.7\end{array}$ & $\begin{array}{r}85.1 \\
60.8 \\
0.3 \\
2,520.8 \\
\ldots\end{array}$ \\
\hline
\end{tabular}

PASTURE IMPROVEMENT UNDER THE STATE

VS. THE EXPERIMENTAL PROGRAM

In order to obtain information relative to the extent of pasture-improvement work being done under the state program as compared with the experimental county program, a study was made of practices carried out in 1939 on a random sample of approximately 150 farms in each of the four counties included in this study. Harrison, Lewis, and Braxton Counties were operating under the regional program.

Table 23-Pasture Improvement on Sample Groups of Farms in Braxton, Lewis, Harrison, and Upshur Counties, 1939

\begin{tabular}{l|c|c|c|c|c}
\hline \hline County & $\begin{array}{c}\text { Number of } \\
\text { farms in } \\
\text { sample } \\
\text { group }\end{array}$ & $\begin{array}{c}\text { Average } \\
\text { size of } \\
\text { farm } \\
\text { (acres) }\end{array}$ & $\begin{array}{c}\text { Average } \\
\text { acres in } \\
\text { non-crop } \\
\text { open } \\
\text { pasture }\end{array}$ & $\begin{array}{c}\text { No. of acres } \\
\text { of pasture } \\
\text { qualifying } \\
\text { for payment } \\
\text { per farm }\end{array}$ & $\begin{array}{c}\text { No. of farms on } \\
\text { which pasture } \\
\text { improvement } \\
\text { practices were } \\
\text { performed }\end{array}$ \\
\hline Braxton & 151 & 109.6 & 53.2 & 40.6 & 6 \\
Lewis & 148 & 172.9 & 123.0 & 13.0 & 27 \\
Harrison & 154 & 154.8 & 106.8 & 91.0 & 35 \\
Upshur & 148 & 79.5 & 34.8 & 30.5 & 87 \\
\hline
\end{tabular}

Tabulations of the soil-building practices carried out on these farms were made in detail from supervisors' reports. 
The data in Table 23 show the number of farms in each sample group, the average size of farms, the acres in non-crop open pasture, the acreage of pasture qualifying for payment, ${ }^{*}$ and the number of farms on which some pasture-improvement practices were carried out.

Harrison and Lewis Counties are somewhat better agricultural areas than are Upshur and Braxton. It can be noted from the table that the average size of farm, the acreage of open pasture, and the acreage of pasture qualifying for payment per farm were all larger in the other counties than in Upshur. Yet, in spite of these conditions, the number of farmers who did some pasture-improvement work in Upshur County was more than twice that in either of the other counties. Fiftynine percent of the sample group of farmers in Upshur County improved their pastures as compared with 23 percent in Harrison, 18 percent in Lewis, and four percent in Braxton County.

The Upshur County group also used more than twice as much lime on pastures as either of the other counties (Table 24). The average amount of lime used per farm for treating pastures in Upshur County was 6,713 pounds of ground limestone or equivalent. This was less than the average quantities per farm in Harrison and Lewis Counties. However, 34 percent of the total quantity of lime used on pastures by the Harrison County group was used on two farms; and 45 percent of the total quantity used in Lewis County was used on one farm. An outstanding accomplishment of the experimental program was its encouragement and assistance to a relatively large number of Upshur County farmers in the application of lime.

Table 24-Lime and Superphosphate Used on Pastures on Sample Groups of Farms in Braxton, Lewis, Harrison, and Upshur Counties, 1939

\begin{tabular}{|c|c|c|c|c|}
\hline County & $\begin{array}{l}\text { Number } \\
\text { of } \\
\text { farms in } \\
\text { sample } \\
\text { group }\end{array}$ & $\begin{array}{l}\text { Number of } \\
\text { farms } \\
\text { reporting } \\
\text { use of } \\
\text { material } \\
\end{array}$ & $\begin{array}{l}\text { Total } \\
\text { pounds } \\
\text { used }\end{array}$ & $\begin{array}{c}\text { Average number } \\
\text { of pounds } \\
\text { used } \\
\text { per farm } \\
\text { renorting } \\
\end{array}$ \\
\hline \multicolumn{5}{|c|}{ Lime } \\
\hline $\begin{array}{l}\text { Braxton } \\
\text { Lewis } \\
\text { Harrison } \\
\text { Upshur }\end{array}$ & $\begin{array}{l}151 \\
148 \\
154 \\
148\end{array}$ & $\begin{array}{r}1 \\
5 \\
11 \\
83\end{array}$ & $\begin{array}{r}500 \\
212,000 \\
200,500 \\
557,230\end{array}$ & $\begin{array}{r}500 \\
42,400 \\
18,227 \\
6,713\end{array}$ \\
\hline & Superphosph & furnished as & conservation material & \\
\hline $\begin{array}{l}\text { Braxton } \\
\text { Lewis } \\
\text { Harrison } \\
\text { Upshur }\end{array}$ & $\begin{array}{l}151 \\
148 \\
154 \\
148\end{array}$ & $\begin{array}{r}5 \\
23 \\
27 \\
24\end{array}$ & $\begin{array}{r}2,550 \\
27,500 \\
34,550 \\
10,750\end{array}$ & $\begin{array}{r}510 \\
1,196 \\
1.280 \\
447\end{array}$ \\
\hline \multicolumn{5}{|c|}{ Purchased superphosphate } \\
\hline $\begin{array}{l}\text { Braxton } \\
\text { Lewis } \\
\text { Harrison } \\
\text { Upshur }\end{array}$ & $\begin{array}{l}151 \\
148 \\
154 \\
148\end{array}$ & $\begin{array}{l}5 \\
6 \\
8 \\
8\end{array}$ & $\begin{array}{r}12,400 \\
2,200 \\
7,720\end{array}$ & $\begin{array}{r}2,480 \\
367 \\
965\end{array}$ \\
\hline
\end{tabular}

*In order to qualify for payment, pasture must be capable of supporting an animal unit on each five acres. 
The number who used superphosphate on pastures in Harrison and Lewis Counties was about the same as in Upshur County. The quantities used in Harrison and Lewis Counties were greater. The phosphate furnished was all high-analysis material. The purchased phosphate is shown in the table in terms of 20-percent equivalent. The experimental program and the educational efforts carried on in connection with it emphasized that best results could be obtained on pastures if both lime and superphosphate were applied. It was also emphasized that the lime application should come first in case the materials were not applied at the same time. Upshur County farmers apparently followed this advice. The data in Table 25 show the number of farmers in each of the sample groups who applied only lime on pastures. Fifty-eight farmers of the group of 148 applied lime alone to pastures in Upshur County. In groups of approximately the same size in the other counties, only four farmers in Harrison County and one each in Lewis and Braxton Counties applied lime alone to pastures.

Table 25-Number of Farms in Sample Groups in Braxton, Lewis, Harrison, and Upshur Counties on Which Lime Alone, Superphosphate Alone, and Lime and Superphosphate Together Were Applied on Pastures, 1939

\begin{tabular}{l|c|c|c|c}
\hline \hline \multirow{2}{*}{ County } & \multicolumn{4}{|c}{ Number of farms } \\
\cline { 2 - 5 } & $\begin{array}{c}\text { In } \\
\text { sample } \\
\text { groups }\end{array}$ & $\begin{array}{c}\text { Using lime } \\
\text { alone on } \\
\text { pastures }\end{array}$ & $\begin{array}{c}\text { Using } \\
\text { superphosphate } \\
\text { alone on } \\
\text { pastures }\end{array}$ & $\begin{array}{c}\text { Using line and } \\
\text { supernhosphate } \\
\text { together on } \\
\text { pastures }\end{array}$ \\
\hline $\begin{array}{l}\text { Braxton } \\
\text { Lewis }\end{array}$ & 151 & 1 & 5 & \\
Harrison & 148 & 1 & 24 & 4 \\
Upshur & 154 & 58 & 26 & 26 \\
\hline
\end{tabular}

Examination of the data in Table 25 also shows that very few of the Upshur County group applied superphosphate alone. In Lewis and Harrison Counties the number who applied superphosphate alone was much larger. This practice was discouraged by the regulation in the experimental county program, which limited payments for application of superphosphate to pasture land that had been treated with lime within the same year or the preceding five years.

Finally, the data in Table 25 show the number of farmers in each group who used lime and superphosphate together. Upshur County farmers were far in the lead with respect to the number using both lime and superphosphate on pastures.

A study of practices carried out on these sample groups of farms indicated that the experimental program achieved results looking toward its objective of bringing about pasture improvement and that the practices were carried out according to recommendations.

West Virginia soils are characteristically acid, and numerous tests with fertilizer and lime in the past have shown far 
better results when lime and superphosphate were used together than when either material was used alone. When used alone on acid soils, much of the nutritive value of superphosphate becomes converted into insoluble compounds through combination with elements in the soil; thus it is rendered unavailable as plant food.

On cropland the practices carried out showed that in Harrison, Braxton, and Lewis Counties much larger acreages were treated with superphosphate than with lime. In Upshur County, the acreage of cropland treated with lime exceeded that on which superphosphate was applied. How much of the acreage receiving the superphosphate applications had been limed before 1939 is not known. It is safe to assume, however, that considerable acreages of cropland were treated without earlier lime application. Tying together the use of lime and superphosphate in connection with seeding practices under the experimental program was effective in discouraging such practice.

Table 26-Crop Acreages Treated with Lime and Superphosphate on Sample Groups of Farms in Upshur, Harrison, Lewis, and Braxton Counties, 1939

\begin{tabular}{c|c|c|c}
\hline County & $\begin{array}{c}\text { Number of } \\
\text { farms in } \\
\text { sample } \\
\text { group }\end{array}$ & $\begin{array}{c}\text { Total crop } \\
\text { acres treated } \\
\text { with } \\
\text { superphosphate }\end{array}$ & $\begin{array}{c}\text { Total crop acres } \\
\text { treated with } \\
\text { lime }\end{array}$ \\
\hline Upshur & 148 & 418.2 & 671.1 \\
Harrison & 154 & $1,382.1$ & 643.9 \\
Lewis & 148 & $1,272.9$ & 416.8 \\
Braxton & 151 & 940.1 & 111.5 \\
\hline
\end{tabular}

The figures in Table 26 show the acreages of cropland treated with lime and superphosphate on the farms in the sample groups in Upshur, Harrison, Lewis, and Braxton Counties in 1939. The tendency to use superphosphate without lime is found also in other areas. For example, in reported results of an animal husbandry contest in Doddridge County in 1939 , 221 of the 286 contestants reported using fertilizer on meadows while 53 used lime. Twelve used lime on pastures and 72 used fertilizer on pastures. * This is indicated also by the fact that 51.5 percent of all farms cooperating in the 1940 program in West Virginia used superphosphate, and 39.4 percent reported the use of ground limestone.

In comparing the foregoing figures for the sample farm groups, the differences in acreages involved should be kept in mind. These differences mean that there were also differences in total soil-building allowances under the conservation programs and differences too in the opportunities for carrying out soil-building practices. A comparison of the total acreages on the sample groups of farms is shown in Table 27.

*West Virginia Farm News Jan,, 1940, p. 15. 
Table 27-Total Acres, Acres in Pasture, and Acres in Crops on Farms in the Sample Groups in Upshur, Braxton, Harrison, and Lewis Counties, 1939

\begin{tabular}{l|c|c|c|c}
\hline County & $\begin{array}{c}\text { Number of } \\
\text { farms in } \\
\text { sample } \\
\text { group }\end{array}$ & $\begin{array}{c}\text { Total acres } \\
\text { in } \\
\text { farms }\end{array}$ & $\begin{array}{c}\text { Acres in } \\
\text { non-crop } \\
\text { pasture }\end{array}$ & $\begin{array}{c}\text { Acres in } \\
\text { crops }\end{array}$ \\
\hline Upshur & 148 & 11,780 & 5,190 & 3,264 \\
Braxton & 151 & 16,542 & 7,878 & 3,979 \\
Harrison & 151 & 23,834 & 16,240 & 6,084 \\
Lewis & 148 & 25,586 & 18,087 & 2.949 \\
\hline
\end{tabular}

The figures in the table show that the totals for the Upshur County farms were considerably smaller in every case than the totals in either of the other counties, with the single exception of the crop acreage on the Lewis County farms.

\section{Seedings}

A large percentage of the total payments to farmers participating in the agricultural conservation program has been for seedings. The returns for the money expended in this part of the program have probably been less than from some of the other provisions. The reason for this is that many farmers have been paid for seedings they would have made anyway. There have been some changes such as increases in acreages sown and in the type of grasses and legumes sown on many farms.

One criticism in connection with seedings in West Virginia is the loss incurred as a result of poor seeding practices. Large acreages are sown each year without attention first being given to the fertility level of the soil. Too often this results in poor stands or crop failure.

Under the experimental program, no credit for seedings was allowed unless lime and superphosphate had been applied to the area in at least minimum specified quantities before seeding. It was felt that this would be a step toward insuring results and away from wasteful seeding practices. As farmers obtained credit under the program for lime and fertilizer applied to soil-conserving crops, the minimum requirements as set up under the experimental program did not appeal as being unfair.

Under the first year of operation of the experimental program, 967 acres which did not qualify for payment were seeded. Under the state program these seedings would have qualified. They did not qualify because the lime and fertilizer requirements were not met. However, as the experimental program continued and as Upshur County farmers became more familiar with its provisions, they changed their practices to conform. There seemed to be general acceptance of the soundness of the requirements as to seedings, and there was little unfavorable reaction. The experimental program was reasonable as to 
minimum requirements, as is indicated by the fact that 1,023 farmers in Upshur County reported new seedings under the 1940 program as compared with 1,101 in Braxton, 1,023 in Harrison, and 744 in Lewis Counties.

The minimum requirements as set up were, in general, far from adequate, but they marked a step in the right direction. Data are not available to show what increases were obtained as a result of the fertilizer and lime requirements with seedings. However, on the basis largely of experience and observation, Upshur County leader's have been enthusiastically impressed with the value of tying together these complementary practices.

\section{Results Obtained Under the Experimental Program}

The experimental program in Upshur County served a useful purpose. Some of the provisions first tried there were later incorporated into the state program. It is believed that both in the county and later in the state program, these changes have had definite benefits and have resulted in a program better suited to the needs of a farming area such as is found in West Virginia.

From the standpoint of one of the outstanding objectives of the experimental program, namely, pasture improvement, the results obtained in Upshur County exceeded the most optimistic early estimates. The shift in three years from an indifferent attitude toward pasture improvement resulting in practically no effort in that direction, to the point where more than a thousand farmers in the county carried out more than 6,900 units of pasture-improvement practices is noteworthy. It is believed also that the educational and demonstrational value of the pasture improvement brought about through the requirements under the experimental program will be reflected in voluntary action for years to come after any such regulation has been removed.

Although the experimental program contained requirements which if not met affected payments under it to a greater extent than did the state program, there is no evidence to show that this had a detrimental effect on participation. This would indicate that if the provisions of a program are recognized as sound and reasonable, they will be accepted, and participation and earnings will be maintained. The agricultural conservation programs are an excellent medium for bringing about desirable practices which, if they depended upon education alone, would be much slower of general adoption.

The agricultural conservation programs have been instrumental in bringing about many improvements on farms in general in this region and in focusing attention on problems of conservation needing attention. This has been particularly true 
made in soil fertility, in land use, in the type and quality of forage crops grown, in the use of cover crops, in woodlot improvement and protection, and in other phases covered by the programs. The financial assistance offered through the programs has brought about progress in conservation over a comparatively short period which would have taken years to achieve on a purely educational basis.

\section{WHAT NEEDS TO BE DONE}

Self-sufficing farms outnumber any other type of farm in the area studied. The problems of these farmers differ from those of farmers primarily engaged in commercial production. It is this low-income group, too, which has benefited least from action programs, research, and extension activities. In the past the work of all of these agencies has largely centered around the commercial farms. The whole problem of the low-income farm needs study, with the ultimate objective of improving the levels of living of these farm families. Such a project is planned and will be undertaken in the near future.

The data thus obtained should aid in answering many questions now arising, such as:

Can the state and regional program be modified in such a way as to meet the particular problems of the low-income group more satisfactorily?

Would it be desirable and practicable to develop a separate set of standards and practices for farms in the low-income classification? The suggestion that this might be done was made in the 1939 preliminary report on this project with the suggested practices centering around the production of the home-produced food supply. The inclusion in the Texas and North Carolina programs in 1940 of the raising of a home garden as an approved practice was a move in this direction. This provision has apparently met with considerable success where it has been tried.

Can low-income farmers intensify their operations profitably through the addition of other enterprises and by increasing the efficiency of those now carried on?

Should more emphasis be placed on cash-crop production on small farms?

Are returns from soil-improvement practices economically justifiable in low-income areas?

Should it be the policy to educate the younger generation in these areas away from the farms? 
What are the opportunities for the development of trades, manufacturing, and home industries in these areas?

Can agriculture in these areas be reorganized and improved to the extent that it will, unaided, provide a fair level of living to a limited population?

How are the costs of public services borne in these areas? Can they be adequately maintained under the present plan by these farming areas without undue burden?

It would appear that the cooperation of many agencies will be necessary in studying the problems and in assisting lowincome farm families to achieve a more desirable level of living. What contribution can be made by each to a coordinated effort can only be determined when detailed data on the situation are available. One advantage possessed by the Agricultural Conservation Program is that it is one agency through which all farms may be reached. A study of its adaptability to the problems of low-income farms would have particular significance.

The discussion has indicated that progress in pasture improvement resulted from the requirements included in the experimental program. That is, a large number of improvement practices were carried out on pastures. These applications of lime and superphosphate were made on pastures varying widely in fertility, slope, soil type, depth of soil, etc. What results were obtained in density of growth, in type of vegetation, and in rate of growth? What returns might one expect from treatments under varying conditions? Under what conditions are pasture treatments economically justified?

Many questions relative to pasture improvement, of which the foregoing are illustrations, still need more definite answers. Effort is now being made to obtain more definite information concerning some of these questions. In the spring of 1940 a cooperative project between the Agricultural Experiment Station and the Bureau of Agricultural Economics of the United States Department of Agriculture was undertaken with the purpose of obtaining objective measurements of changes resulting from pasture treatments. With the cooperation of Upshur County farmers such studies were carried out on 23 farms in 1940 and were continued during 1941 on 25 farms. Although all farmers cooperating indicated that pasture-improvement practices were profitable, the data from these studies will furnish definite evidence as to the extent of the improvement obtained.

Another problem which needs particular attention is that of pasture management. The benefits obtained through pasture treatment can easily be offset by unwise management prac- 
tices such as too early or too late grazing, overgrazing, failure to adjust pasture loads or to follow rotation practices, etc. The outstanding problem, as previously indicated, is the all too common practice of leaving cattle on pasture the year 'round.

How much damage is done to pastures by the trampling of cattle during the late fall, winter, and early spring? What is the effect on yield, early growth, carrying capacity, rate of gain, etc.? What advantages in costs of wintering are gained? Observation and experience indicate considerable damage to pastures as a result of year-round pasturing practice. Objective measurements and tests would be instrumental in speeding the adoption of more desirable pasture-management practices. Special educational effort in this direction is desirable if maximum benefits are to be obtained from applications of lime and fertilizer on pastures.

That special emphasis on the educational phases of the Agricultural Conservation Program would be mutually helpful to farmers and to the objectives of the program, particularly in connection with individual conferences and with the development of farm plans, was indicated by data obtained in this study.

\section{SUMMARY}

A study of available information has shown that farm organization in the counties comprising the north-central pasture area of the state is quite similar.

The conclusion that any program well suited to the needs of one county should be reasonably well adapted to all in the same type-of-farming area is sound.

The experimental county program, in spite of its additional requirements, was accepted with little opposition.

The experimental program was instrumental in bringing about far more pasture improvement in Upshur County than was accomplished on farms in adjacent counties operating under the state program.

The Agricultural Conservation Program is an effective medium through which the adoption of reasonable and desirable farm practices might be furthered.

The supplying of conservation materials in lieu of payment greatly stimulated their use, both as to amount and widespread application.

The results obtained on pastures following the applications of lime and superphosphate have been such as to build up en- 
thusiastic support in Upshur County for a regular plan of pasture improvement.

The use of lime and superphosphate in connection with new seedings also demonstrated to large numbers of farmers the value of considering the acidity and fertility of the seedbed if best results were to be realized.

Because of small farm allowances and the fact that the little farms were among the last to cooperate in the conservation programs, the low-income group of farms has probably benefited less from the programs than any other type-of-farming group.

The pasture problem is outstanding in the area because of the dependence placed by farmers on livestock enterprises for cash income and because of the quality of pastures, with their customary lack of attention.

More emphasis placed on the educational phase of the program would be beneficial.

Farmers found personal interviews to be the most satisfactory source of information on the program. 
